\title{
THE INFLUENCES OF FOREIGN DIRECT INVESTMENTS, INTRAFIRM TRADING, AND CURRENCY UNDERVALUATION ON U.S. FIRM TRADE DISPUTES*
}

by

\author{
J. Bradford Jensen \\ Georgetown University
}

\author{
Dennis P. Quinn \\ Georgetown University
}

Stephen Weymouth

Georgetown University

\section{CES 14-04 January, 2014}

The research program of the Center for Economic Studies (CES) produces a wide range of economic analyses to improve the statistical programs of the U.S. Census Bureau. Many of these analyses take the form of CES research papers. The papers have not undergone the review accorded Census Bureau publications and no endorsement should be inferred. Any opinions and conclusions expressed herein are those of the author(s) and do not necessarily represent the views of the U.S. Census Bureau. All results have been reviewed to ensure that no confidential information is disclosed. Republication in whole or part must be cleared with the authors.

To obtain information about the series, see www.census.gov/ces or contact Fariha Kamal, Editor, Discussion Papers, U.S. Census Bureau, Center for Economic Studies 2K132B, 4600 Silver Hill Road, Washington, DC 20233, CES.Papers.List@census.gov. 


\begin{abstract}
We use the case of a puzzling decline in U.S. firm antidumping (AD) filings to explore how firm-level economic heterogeneity within U.S. industries influences political and regulatory responses to changes in the global economy. Firms exhibit heterogeneity both within and across industries regarding foreign direct investment. We propose that firms making vertical, or resource-seeking, investments abroad will be less likely to file AD petitions. Hence, we argue, the increasing vertical FDI of U.S. firms (particularly in countries with undervalued currencies) makes trade disputes far less likely. We use firm level data to examine the universe of U.S. manufacturing firms and find that $\mathrm{AD}$ filers generally conduct no intrafirm trade with filedagainst countries. Among U.S. MNCs, the number of AD filings is negatively associated with increases in the level of intrafirm trade for large firms. In the context of currency undervaluation, we confirm the existing finding that undervaluation is associated with more AD filings. We also find, however, that high levels of related-party imports from countries with undervalued currencies significantly decrease the numbers of AD filings. Our study highlights the centrality of global production networks in understanding political mobilization over international economic policy. [192]
\end{abstract}

\footnotetext{
${ }^{*}$ Some of the analysis in the paper was conducted at the Center for Economic Studies at the U.S. Census Bureau. Any opinions and conclusions expressed herein are those of the authors and do not necessarily represent the views of the U.S. Census Bureau. All results have been reviewed to ensure that no confidential information is disclosed. The statistical analysis of firm-level data on U.S. multinational companies was conducted at the Bureau of Economic Analysis, U.S. Department of Commerce, under arrangements that maintain legal confidentiality requirements. The views expressed are those of the authors and do not reflect official positions of the U.S. Department of Commerce. We thank the International Monetary Fund and its Research Department for financial support. Rachel Szymanski provided excellent research assistance. We thank Bill Zeile of the Bureau of Economic Analysis, Kristin Corwin at the Census Bureau for producing customized aggregates from Census trade data, and Jim Davis of the Boston Research Data Center. The views expressed herein are those of the authors and do not necessarily reflect the views of the National Bureau of Economic Research.
} 
Recent advances in international economics offer strong theory and empirical evidence explaining why some firms in an industry trade internationally and undertake foreign direct investments, while other firms in the same industry do not. Firm-level heterogeneity within an industry -- and not industry or factor advantages per se -- is the fundamental determinant of trade and international investment activities. ${ }^{1}$ The literature explains and demonstrates how firms with different characteristics respond differently to a change in the economic environment (e.g., in response to trade liberalization, some firms expand their exports while other firms shut down).

This intraindustry heterogeneity is likely to have important political implications because many aspects of U.S. trade, regulatory, competition, and tax policies have historically assumed some degree of intraindustry economic homogeneity and a concomitant commonality of political interests among firms within the same industry. ${ }^{2}$ We propose that firm-level variation in global production strategies will likely be associated with intraindustry heterogeneity in political preferences for economic policy. Changes in the composition and characteristics of firms might, therefore, result in increased difficulties within industries over time in organizing politically to achieve common policy goals.

We use U.S. firm antidumping (AD) filings to explore the effects of intraindustry economic heterogeneity in foreign direct investment on firm political activities. The relevant intraindustry variation in our study involves the location of firm foreign direct investments as well as diversity in trade relationships among firms with (and without) foreign affiliates. Our motivating puzzle is that the number of antidumping (AD) trade filings by U.S. firms has

1. Bernard and Jensen 1999; Bernard et al. 2007, 2009; Melitz 2003.

2. For example, corporate tax policy is generally set at an industry level in terms of exemptions, investment tax credits, and the like. 
declined markedly in the past 10 years even though known determinants of AD filings, especially import surges from countries with undervalued currencies, have increased. ${ }^{3}$ (See Figure 1.)

We argue and offer supporting evidence that the expansion of global supply chains by U.S. multinational corporations helps explain the decline in AD filings-increasing import competition, long run trade deficits, and persistent foreign currency undervaluations notwithstanding. As more firms undertake FDI and trade intrafirm with their affiliates in a country, especially a country with an undervalued currency, the likelihood of an AD filing against that country’s firms diminishes markedly. The growing market shares of MNCs with FDI and intrafirm trading (as shown below) across many industry segments make the legally mandated 25 percent market share "threshold requirements” for a U.S. antidumping filing mandate ${ }^{4}$ increasingly difficult to meet in more and more product categories.

The paper is organized into three main sections. The first section explores the political and economic interrelationships between and among international trade and investment, undervalued currencies, and trade disputes. In this section, we develop an argument linking increased firm participation in vertical production networks to decreased AD filings, and we present empirical implications of the argument.

In the empirical analysis section, we exploit firm level data to examine our claims. First, we analyze the universe of U.S. manufacturing firms covered by the U.S. Economic Census to

3. See Broz and Werfel 2013 and Ludema and Mayda 2011 on the role of currency undervaluation and import competition, respectively, on AD filings.

4. The law requires that the filing be supported by the producers of 25 percent of either the total volume, or value, of the production of the 'domestic-like' product. See the discussion below. 
provide descriptive statistics regarding the attributes of firms that file antidumping petitions compared to their product market industry peers. We examine a subsample of filers at a point in time (1993) and examine the attributes of non-surviving and surviving filers to 2009, comparing both groups to non-filing industry peers. Filers are larger and more internationally engaged than industry peers, but not in the countries that they file against. Surviving filers are more internationally engaged than non-surviving filers, and become more internationally engaged, establishing affiliates in countries with undervalued currencies from which they import.

We next examine the universe of U.S multinational corporations (MNCs) using data collected by the Bureau of Economic Analysis, and explore how the forms and magnitudes of their international supply chains influence the likelihood of MNC AD filings. An appealing attribute of this analysis is that we are able to decompose a firm's supply chain into within firm (or intrafirm or "related-party") trading and arm's-length (or unaffiliated party) trading. We find that intrafirm trading significantly reduces the likelihood of AD petitions filings for large firms ( $\$ 1.3$ billion in sales and above).

An implication of our argument is that some firms will respond to sustained currency undervaluations by setting up affiliates for the purpose of production and related-party trade. In the third part of the empirical analysis, we provide evidence that currency undervaluations are associated with increased U.S. FDI in the target country, especially vertical (or resource-seeking) FDI.

Many scholarly studies have found that currency undervaluations in partner countries are a robust correlate of AD filings. ${ }^{5}$ We next move to the macro-country level and examine the implications of our argument in light of these prior findings. We confirm the robust positive

5. See, e.g., Broz and Werfel 2013; Knetter and Prusa 2003. 
association between foreign currency undervaluation and increased AD filings. We also show, consistent with our argument, that the relationship between undervaluation and disputes has a strong interactive effect with different types of trade flows. In particular, high levels of relatedparty trading in the context of currency undervaluation sharply diminishes the likelihood of AD filings.

In the final empirical part, we examine China separately because it is almost uniquely identified in U.S. trade law as a 'non-market' economy. We show that the number of filings predicted by our empirical model nearly matches the actual number of U.S. firm AD filings. The key explanatory variables are changes in the composition of trade flows, with related-party trade associated with fewer disputes.

Our conclusion is that firm heterogeneity in global sourcing activities drives firm political and economic responses to the economic policies of U.S. trade partners, particularly currency undervaluation. In the current era of increasing import competition, it is not a firm's sectoral advantages, its industry, or even its international orientation per se that determines its response to the policies of foreign trade partners. Rather, a firm's direct investments and associated relatedparty trade relationships in a specific country at a point in time shape its economic and political activities: a salient political economic cleavage divides firms with trade-related foreign affiliates from those without.

\section{Global Sourcing Activities and Firm Antidumping Filings}

Three political economic considerations motivate our analysis. These include: the increasing prevalence of global supply chains found across many U.S. industries, ${ }^{6}$ persistent currency

6. Bernard, Jensen, and Schott 2009; Ramondo, Rappoport, and Ruhl 2013. 
undervaluations in many U.S. trade partner country currencies, and the ongoing opportunity to use temporary trade barriers, including antidumping, by firms and industries facing competitive import pressures. Below we discuss how firm global supply chains affect the use of temporary trade barriers by firms, especially in the context of currency undervaluation.

\section{Empirical Puzzle}

As tariff rates steadily decline globally, temporary trade barriers (TTBs) have become an important political recourse, and antidumping duties are by far the most commonly employed TTB worldwide. ${ }^{7}$ We consider AD filings in the United States, where individual firms, groups of firms, and labor unions, representing at least $25 \%$ of U.S. production of a product, initiate the investigations by filing a petition with the Department of Commerce (DOC). The International Trade Administration (ITA) of the DOC next determines whether foreign goods have been sold at less than fair value (“dumped”), defined as a price below that which they are sold in the home market or below an estimate of average total cost. Filings correlate strongly with policy changes by trade partners that are unfavorable to filers ${ }^{8}$ and successful filings can bring significant economic advantage to filers. ${ }^{9}$ A couple of questions arise in light of prior findings: why, if AD filings bring advantages to successful filers, have filings declined over time? Does variation in firm investment and trade activities explain why some firms are less likely to file?

7. Irwin 2005; Bown 2011.

8. Broz and Werfel 2013; Knetter and Prusa 2003.

9. Bechtel and Sattler 2012. 


\section{Variation in Firm International Engagement}

In explaining firm responses to import competition from foreign trade partners, we propose that a firm's establishment of global supply chains (i.e., the firm's foreign direct investment and associated related-party trade) is a crucial explanatory variable. Prior scholarship stressed the centrality of whether firms were internationally engaged or not for their political engagement on trade issues. ${ }^{10}$ Here, we allow for a firm's political engagement on trade issues to vary by country and by year according to the nature of its investment and trade relationships.

Empirical research provides a rich picture of firm participation in international trade and investment. Figure 2 illustrates the activities and concentration of globally engaged U.S. firms. First, among the universe of all U.S. firms, engaging in international trade is rare. According to Bernard et al., only around 3\% of U.S. firms trade internationally (and just 1\% of U.S. firms both import and export). ${ }^{11}$ Most firms that trade do so only at “arm's-length”: that is, with unaffiliated parties.

However, a small number of firms (“Multinationals”) establish affiliates in foreign countries, some for the purpose of exploiting differences in relative factor endowments to produce at lower cost (vertical FDI). By an accounting definition, FDI precedes related-party, or intrafirm, trade with foreign affiliates. While exporters are larger, more productive, and more capital-intensive than non-exporters, multinationals are yet larger and more productive than firms that strictly export. ${ }^{12}$ MNCs anchor global supply chains, mediating nearly 90 percent of U.S.

10. The seminal contribution is Milner 1988.

11. Bernard, Jensen, and Schott 2009.

12. Tomiura 2007; Yeaple 2009. 
exports and imports. ${ }^{13}$ This includes, by definition, all related-party trade, and the vast majority of arm's-length imports and exports. While MNCs may choose to source from related parties or at arm's-length, only intrafirm trade implies investment in, and thus greater economic integration with, foreign host countries.

In addition to mediating a large share of international trade, MNCs account for a sizable share of economic activity in the U.S., representing over 27 percent of employment in 2000 and accounting for more than a third of net job creation in the private sector over the 1993-2000 period. ${ }^{14}$

Multinationals are dispersed across a wide array of industries. Ramondo, Rappoport, and Ruhl find high degrees of intra-industry heterogeneity across manufacturing industries in terms of the intensity of intrafirm trading. ${ }^{15}$

We argue and show below that the combination of the intrafirm trade activities of MNCs and their relatively large size help explain the decline in firm AD filings. Large firms with vertical foreign direct investments are unlikely to seek protection through AD, even in the face of increased import competition from countries with undervalued currencies.

13. Bernard, Jensen, and Schott 2009.

14. See Bernard, Jensen, and Schott, 2009.

15. Ramondo, Rappoport, and Ruhl 2013 create an index of intrafirm 'intensity.' Aggregating data to the two digit International Standard Industry (ISI) groupings, they show that firms at the 75th percentile of intrafirm intensities have very similar intensity rankings across the entire range of manufacturing industries (Table 6, panel 1, p. 30). They also find extensive heterogeneity in the intensity of intrafirm trade within 3-digit NAICS-ISI industry codes. 
Our explanation departs from the much of the prior literature on the political economy of trade, which considers divisions over trade policies by industries or sectors of the economy. Trade models that assume that firms are homogeneous within either industries or sectors lead to the inference that trade affects firms in a given industry or sector in the same way. ${ }^{16}$ In contrast, we examine the political implications of recent advances in the economics of international trade, which sees firms, not industries or sectors, as the central mediators of international commerce. ${ }^{17}$ The within industry heterogeneity in firm internationalization, and the greater size of MNCs relative to domestic peers, are relevant considerations for antidumping filings and trade protectionism more broadly for two reasons. First, the threshold requirements for a U.S.

16. Models that adopt a two-factor Heckscher-Ohlin framework with Stolper-Samuelson distributional effects predict class cleavages over international economic policy (Rogowski 1987). Models that assume costly intra-industry factor mobility along the lines of Ricardo-Viner imply homogeneous trade policy preferences among firms and workers in the same sector. (See Hiscox 2001; Magee 1980). Neither approach explains well the observed intra-industry variation in protectionist demands, or inter-temporal changes in a given firm's economic and political responses to undervaluation. Our argument is closer in spirit to Milner 1988, who shows that increases in a firm's international economic orientation reduce demands for import protection. 17. The "heterogeneous firm" trade models emerged out of research by Bernard and Jensen $(1995,1999)$, who were some of the first authors to exploit micro datasets to study variation in exporting (and later importing) behavior at the plant- and firm-level. Melitz’s (2003) model advanced a theoretical explanation by showing that only the largest and most productive firms can generate sufficient profits to cover positive fixed exporting costs; thus productivity helps explain why firms self-select into trade. 
antidumping filing mandate that the filing be supported by the producers of 25 percent of either the total volume or value of the production of the 'domestic-like' product. ${ }^{18}$ The greater the number of large firms with trade linkages to a particular country, the more difficult it becomes to organize the relevant filing coalition against that country. And, the largest producers in an industry, which tend to be MNCs, ${ }^{19}$ are likely to have greater standing in either filing or, more relevantly for this paper, refusing to file petitions.

Secondly, as Greir, Munger, and Roberts noted, larger firms have had greater success in overcoming collective action problems in organizing industry rivals politically compared to the hurdles facing more atomistic industries composed of smaller firms. ${ }^{20}$ MNCs are therefore not only economically consequential; their size gives them greater capacity to organize politically for or against filings.

We propose, therefore, that variation in foreign direct investment positions and subsequent related-party trade flows will affect a firm's decision to initiate, or join with industry peers, in an AD filing. MNCs with substantial FDI abroad are less likely to file AD, and, as the number of firms with international investment activities grows, especially in countries with undervalued currencies, the number of $\mathrm{AD}$ filings is likely to fall.

Undervaluation, Global Production Networks, and Firm AD Filings

18. For a detailed description, see http://ia.ita.doc.gov/petitioncounseling/pcp-industrysupport.html

19. Bernard et al. 2009.

20. Greir, Munger, and Roberts 1994. 
Two ideal-type strategies regarding export promotion have been influential among emerging market economies in recent decades. As the main example of one, the high performing East Asian economies, most notably China, have been characterized during their rapid growth experiences by active exchange rate management policies that led to currency depreciation and export surges. ${ }^{21}$ The other ideal-type strategy, of which Mexico has been an exemplar, is characterized by extensive participation in bilateral and international trade agreements, open capital markets, and a floating, market determined, exchange rate. ${ }^{22}$ The latter strategy limits the use of systematic currency undervaluation as a governmental policy option for export promotion. ${ }^{23}$

To illustrate currency undervaluation vs. overvaluation graphically, we refer to Figure 3, which shows the evolution of currency valuations over time for China and Mexico, which despite their policy stance differences - have very similar factor endowments. ${ }^{24}$ (Please see the data appendix for details on construction of the undervaluation index. ${ }^{25}$ ) Excluding the period of

21. Page 1994; World Bank 1993.

22. Mexico has signed free trade agreements with 44 countries, including the United States, Japan, Canada, and the member countries of the European Union (Villareal 2012).

23. Copelovitch and Pevehouse (2013), however, find that a PTA with a primary economic partner (the country to which the currency is pegged or the most important trade partner) is associated with exchange rate flexibility and a depreciated real exchange rate.

24. See Chiquiar et al. 2008 for a detailed comparison of the factor endowments and the wide range of product market competition between the two economies.

25. Somewhat counter-intuitively, the convention in the field is to denote undervaluation with positive numbers and overvaluation with negative numbers. Zero is a neutral valuation. 
the Mexican Peso Crisis, the post NAFTA Mexican peso ceased its long-run undervaluation and was on average overvalued relative to the U.S. dollar. China, as part of its economic reforms in the 1980s, ended its long-standing currency overvaluation. Since the 2000s, China has sustained an undervalued exchange rate compared to the Mexican peso’s overvaluation, which gave U.S. producers an incentive to invest in and source from China rather than from Mexico.

Currency undervaluation may be a particularly attractive growth strategy for governments ${ }^{26}$ because the international trading system under WTO rules does not proscribe countries from engaging in currency undervaluation for the purposes of export promotion. ${ }^{27}$ Copelovitch and Pevehouse, for example, find that governments that have signed preferential trade agreements (PTAs) are likely to subsequently move to an undervalued currency vis-à-vis the PTA partners' currency, possibly so as to enhance export competitiveness relative to their PTA partners. ${ }^{28}$

While an undervalued currency may offer economic advantages to exporting nations and their firms, undervaluation risks backlash through other means by foreign trade partners. Some governments, in the extreme, undertake policies to lessen the effects of the depreciations of trading partner currencies through competitive devaluations. ${ }^{29}$

26. On the link between the exchange rate and growth, see Fisher 1993; Easterly 2005; and Rodrik 2008. In an influential paper, Rodrik (2008, p. 366) finds “an increase in undervaluation boosts economic growth just as powerfully as a decrease in overvaluation.”

27. Sanford 2011.

28. Copelovitch and Pevehouse 2013.

29. For example, Brazil, Israel, Japan, New Zealand, Poland, and Switzerland have recently undertaken monetary or exchange policies targeted at lessening the value of their currencies. 
Firms and industries can respond to undervaluation by trade partners by filing for temporary trade remedies such as antidumping. Numerous studies have indeed found a strong correlation between domestic (home country) real exchange rate appreciation vis-à-vis trade partners, and subsequent trade disputes. ${ }^{30}$ The central inference of this research is that AD filings represent the response of particular industries to undervaluation among trade partners. In particular, Broz and Werfel show that the pass-through of exchange rate movements to prices, which varies systematically by industry, correlates with industry responses to domestic real exchange rate fluctuations. ${ }^{31}$

We propose to extend the literature by considering how firm participation in global production networks shapes firm political strategies in the context of increased trade competition. In particular, our argument suggests that firms integrated in global supply chains, particularly those in countries with undervalued currencies, will be less likely to pursue antidumping. A depreciated currency makes the value of assets relatively cheaper in foreign currency terms, lowering the costs of investment by foreign firms, and increasing the net worth of foreign bidders relative to domestic investors. ${ }^{32}$ Furthermore, following the comparative advantage motive for vertical FDI, firms tend to produce abroad where they can take advantage of cheaper inputs. ${ }^{33} \mathrm{~A}$ depreciated currency lowers the cost of labor and other host-country inputs relative to production

30. Broz and Werfel 2013; Copelovitch and Pevehouse 2011; Irwin 2005; Knetter and Prusa 2003; and Oatley 2010.

31. Broz and Werfel 2013.

32. Blonigen 1997; Froot and Stein 1991.

33. Helpman 1984. 
costs in the home country. ${ }^{34}$ For firms that use FDI as a platform for export, a depreciated currency increases the competitiveness of exports from that platform. ${ }^{35}$

Our argument suggests that firms engaged in foreign direct investment and intrafirm trade are less likely to file AD petitions against countries in their supply chains. Their lack of political mobilization over potentially harmful policies such as undervaluation may derive from the material benefits they accrue from investing abroad, which include cheaper foreign assets, more competitive platform exports, and lower production costs. As a result, firms that participate in global production networks will be unlikely to file against firms in their host country.

In contrast, large firms that are engaged in international trade and investment, but that do not have trade or investment relationships with an undervalued country, may pursue trade remedies, especially if they compete with relatively cheaper imports from countries with undervalued currencies. ${ }^{36}$ (See Gawande, Hoekman, and Cui for the development of a related argument in the context of seven large emerging market countries. ${ }^{37}$ )

\section{Empirical Implications of Our Argument}

Our argument has several empirical implications that we examine at the firm- and country-level. At the level of the firm, we expect differences in international investment

34. Goldberg and Kim 1997.

35. Blonigen 1997.

36. Analyzing antidumping filings in Canada, Ludema and Mayda 2011 find that Canadian firms that compete against Chinese imports are the ones seeking protection.

37. Gawande, Hoekman, and Cui 2013. 
positions and in the composition of trade flows among firms that file AD petitions compared to those that do not. Compared to their non-filing peers, filers will conduct less related-party trade with filed-against countries, particularly in the product category in which they reside. We also expect firms with high levels of intrafirm trade (i.e., trade with global affiliates) to file fewer AD disputes.

At the country-level, we follow recent literature examining the specific relationship between undervaluation and $\mathrm{AD}$ filings. Our argument extends the literature in that we expect that the impact of undervaluation on AD filings will depend on the composition of trade flows originating from countries pursuing undervaluation. We proxy for integration with the U.S. using measures of FDI and intrafirm trade. We expect undervaluation to be associated with fewer AD filings against countries from which higher levels of U.S. intrafirm imports originate.

While we expect this pattern to hold probabilistically across U.S. trade partners, antidumping filings and trade disputes with China are likely to represent a special case, as China is labeled a "non-market economy" under both the terms of China's accession to the WTO and its prior treatment under U.S. trade legislation. ${ }^{38}$ Over the past three decades, U.S. antidumping petitions against China account for $13.8 \%$ of all filed disputes. The growing direct investments by U.S. MNCs in China and the resulting related-party trading with China will change the political calculus of these participant firms regarding antidumping duties. MNCs with export-

38. See Messerlin 2004; and Rumbaugh and Blancher 2004. As Rumbaugh and Blancher note (2004, 8), under the WTO agreement, “other members can invoke "non-market economy" provisions to determine dumping cases for 15 years following [China's] accession.” See especially Prusa and Vermulst 2013, 219-23. Vietnam is the other country that the U.S. labels as a non-market economy. 
platform operations in China benefit from low-cost intermediate goods produced and final goods assembled in China; firms without such operations and which compete with Chinese exports will be harmed by an undervalued Yuan.

\section{Empirical Analyses}

In this section, we explore the empirical implications of our argument using data from multiple sources at different levels of analysis. First, we examine data on the universe of U.S. manufacturing firms to compare the trade and investment profile of $\mathrm{AD}$ petition filers to their non-filing peers. We then turn to data on the universe of U.S. multinationals to probe the firmlevel correlates of AD filings, paying particular attention to the source of trade flows among MNCs. At the firm level, we examine the relationship between undervaluation and the type of foreign direct investment. At the country level, we analyze the relationship between foreign currency undervaluation, trade flows, and U.S. AD dispute filings.

\section{Characteristics of Antidumping Petition Filers}

Our hypothesis is that firms that are engaged in trade with a country, particularly relatedparty trade with their foreign affiliates, will be less likely to file antidumping petitions. We compare filers to non-filers in the same product market for evidence that filers are different. We focus specifically on the relative size of filers, their overall international engagement (imports and exports), and their engagement with the country against which they file (in terms of arm'slength trade and related-party trade). 
Our data source for AD petitions is the May 2012 update of the Global antidumping Database created by Chad Bown (GAD-USA.xls). ${ }^{39}$ (The Data Appendix describes the data sources and defines several of the variables in greater detail.)

Our source of firm-level data is the Census Bureau Linked/Longitudinal Firm Trade Transaction Database (LFTTD), covering the universe of firms in the scope of the economic census. ${ }^{40}$ (This is, to our knowledge, the first use of these data in the political science literature. See the Data Appendix for a description of the data.)

The results are presented in Table 1. A total of 559 organizations, including firms, trade associations, unions, and other organizations, filed antidumping petitions over the period 19932009. We are able to match 425 of these organizations to the Census Bureau's Business Register, an excellent match rate of 76 percent considering that not all filers are private sector firms.

[Table 1 about here]

Firms that file antidumping petitions are relatively large within their industries, having an average rank of the 88th percentile in terms of employment within their product market industry (line 1). At least $75 \%$ of the antidumping petition filers are engaged in international trade, and they are above the median in terms of value of merchandise exports and merchandise imports: filing firms have an average rank of 74th percentile in terms of overall exports (the sum of arm'slength and related-party exports) and 68th percentile in terms of overall imports (lines 2 and 3, respectively). Most of the filing firms are vertically-integrated MNCs: nearly $60 \%$ of them engage in related-party trading, and the percentile rank of value is high. Relatively few of the

39. Bown 2012.For applications of the data, see Pierce 2011 and Bown and Crowley (2013a,b). 40. Our analysis begins in 1993 because this is the first year LFTTD data is available. 
filers are purely exporters to or importers from unaffiliated parties. In sum, we find that the average antidumping filing firm is a very large, internationally engaged firm.

In terms of trade within the product category with the country that the firm files against, we find, perhaps not surprisingly, that only roughly a quarter of antidumping filers are exporting or importing in the product category with the filed against countries. The firms that are so engaged are below the median in terms the values of overall imports and exports.

We find that filers are quite small relative to other participants in their industry in terms of related-party trade in the product category with the target country. Only $12 \%$ engage in related-party trading in the same product category, and of those firms who do, the value is modest compared to industry peers. ${ }^{41}$ The vast majority of filers (88\%) have zero related-party imports and exports with the country against which they file. Consistent with our argument, antidumping filers, on average, have much smaller investment and trade relationships with targeted countries in the product categories in which they file.

We further examine how filing firm characteristics evolve over time and we report our findings in Figure 4. We take the sample of firms that file in the 1993-1997 period and examine their international trade characteristics in 1993. Figure 4 presents international trade statistics for the 89 firms that filed in the 1993-1997 period, 41 of whom subsequently failed and 48 of which survived. The 2009 data for the 48 survivors are also presented. (Additional data for the 89 firms are also discussed and are available from the authors upon request.)

[Figure 4 here]

41. These firms are in only the 21st percentile in terms of related-party exports (within product category to the target of the petition) and the 21st percentile in terms of related-party imports (within product category from the target of the petition). 
Surviving firms were generally internationally engaged in exporting, importing and related-party exporting in 1993, relative to all firms and to non-surviving filers. At least a quarter of the 48 survivors were engaged in trade in the four digit product with the set of countries filed against for the period 1993-1997. ${ }^{42}$ In contrast, a much smaller proportion of the 41 failing firms engaged in related-party trading in the product with the set of countries filed against 1993-1997.

Twenty-six years later, the general international profile of the surviving filers was little changed: they remained larger and more internationally engaged than their product market peers (percentile ranks not reported in figure but available upon request). The share of surviving filing firms engaged in exporting to a country that was filed against 1993-1997 increased by 13 percent and the share of surviving filing firms engaged in related-party importing from a country that was filed against increased 8 percent.

We observe a notable increase in firms' engagement with undervalued countries compared to those with overvalued currencies. We separate countries into two groups based on the average value of our undervaluation index over the period 1990 through 2009: countries with sustained undervalued currencies and countries with sustained overvalued currencies. (The derivation of the undervaluation index is detailed in the Data Appendix). Figure 4 shows that the share of surviving filing firms that trade with undervalued countries increased significantly particularly related-party importing that increased 23 percent - while the share of firms engaged with overvalued countries marginally decreased. AD filing firms that survived increased their

42. We construct a list of HS 4-digit product and country pairs that were filed against during 1993-1997. We report that share of firms (or share employment at firms) engaged in trade with the filed against product-country pair in Figures 4, 5, and 6. 
international trade with countries with undervalued currencies. If, as we show below, firms with vertical affiliates are less likely to file AD, then disputes against countries pursuing undervaluation should decline.

[Figure 5 here]

While we are particularly interested in the changing nature of the international activities of filers, we observe that similar changes in trading relationships are also evident in the sample of all surviving manufacturing firms. Figure 5 presents the same statistics as those reported in Figure 4 (though in Figure 5 we report employment weighted shares as a proxy for market share). While the overall engagement in international trade (i.e., exporting, importing, RP exporting, RP importing) changed little among surviving manufacturing firms between 1993 and 2009, firms undertook modest increased engagement with countries that were filed against 1993-1997, but significant increases in trade with undervalued countries. The share of employment at firms with imports from undervalued countries increased 11 percent. The share of employment at firms that engage in RP imports from undervalued countries increased 17 percent, and by 2009 is nearly three times greater than the share of non-survivors with intrafirm imports from undervalued countries in 1993.

Last, we examine the prevalence of international engagement for all manufacturing firms in 1993 and 2009 to examine whether the changing trade patterns for filers and surviving firms are reflected in the cross-sections of firms in 1993 and 2009. Figure 6 displays changes in employment-weighted means for all manufacturing firms in 1993 versus 2009. The share of employment at manufacturing firms with overall international trade decreased slightly over the period. The employment-weighted proportion of firms engaged with countries that were filed against 1993-1997 increased modestly. We observe modest declines in activities in countries 
with overvalued currencies, while the share of employment at firms with trade with undervalued countries increased, particularly at firms with RP imports from undervalued countries, which increased 13 percentage points.

[Figure 6 here]

In sum, we find that filing firms are larger and more internationally engaged than the average firm, though filers do not trade with the countries they file against. Surviving filing firms are larger and more internationally engaged; and they have increased their international trade with countries that were filed against, and with undervalued countries. The changes at surviving filing firms are reflected in surviving manufacturing firms overall - surviving firms have increased their trade engagement with countries that were filed against and, particularly, with undervalued countries. These changes are reflected in the aggregate market shares of firms engaged with undervalued countries. The rising share of economic activity accounted for by firms with affiliates in countries with undervalued currencies makes organizing a coalition representing 25 percent of activity in a product market increasingly difficult. The results are consistent with our argument that the increasing prevalence of trade with undervalued countries reduces the constituency for $\mathrm{AD}$ filings.

Firm-Level Correlates of AD Petition Filings: Intrafirm Trade and U.S. MNCs

Another empirical implication of our argument is that firms with extensive vertical foreign direct investment and large volumes of trade with their global affiliates will be less likely to file AD petitions. In this section, we seek to differentiate firm participation in global production networks from arm’s-length trade activities using a regression framework. 
To that end, we link trade data from the universe of U.S. multinationals covered in the scope of the BEA Benchmark Surveys 1989-2009 with the data on AD petition filers to examine the correlates of AD filings at the firm level. ${ }^{43}$ One hundred and seventy AD filers are U.S. MNCs covered in at least one of the BEA Benchmarks surveys. The BEA data allow us to observe the value of trade (total imports and exports) conducted by the headquarters of all U.S. MNCs. The import and export values are further disaggregated according to the headquarter firms’ relationships with trade partners: unaffiliated trade is trade conducted with firms and organizations that are not foreign affiliates of the headquarters firm; related-party trade is trade with foreign affiliates of the MNC. ${ }^{44}$

We examine the correlates of AD petition filings at the firm level. We estimate variations of the following model of the number of dispute filings for firm $i$ : 
where $t$ corresponds to each year of the quinquennial BEA Benchmark Survey over the period 1989-2009. Our specification includes year fixed effects to capture global trends. ${ }^{45}$ Firm fixed effects are inappropriate in this context, as only firms with filings would enter the analysis, resulting in a biased sample. ${ }^{46}$

The AD filing data are highly overdispersed, with more than $99.8 \%$ of summed AD dispute observations equal to zero. To address overdispersion in the data, we follow the literature in assuming and testing that the data are best examined with a zero inflated negative binomial model due to the very large number of zeros. ${ }^{47}$

We report the estimates of AD dispute filings at the level of the U.S. MNC in Table 2. The estimates from the parsimonious baseline specification reported in column 1 indicate that the volume of trade conducted with global affiliates (Related-Party Trade) is negatively associated with AD dispute filings, while Arm's-Length Trade is positively associated with filings. In model 2, we introduce the log of total MNC sales as a proxy for firm size, and sector fixed effects. Related-Party Trade retains a negative and statistically significant coefficient, but the coefficient corresponding to Arm's-Length Trade is dramatically reduced. In column 3, we

45. We also ran estimations with a time trend, and the results were little changed.

46. However, we relax the assumption of i.i.d standard errors, and report estimates that allow for firm-level clustering.

47. See Hilbe 2011 for a discussion. To account for prevalence of zero-value observations, investigators use zero inflated negative binomial models. We use the logged value of total trade as the predictor of overdispersion, or 'excess' zeros. A Vuong test comparing the zero-inflated negative binomial model to the standard negative binomial model indicates that the zero-inflated negative binomial model is the more appropriate specification. 
restrict the sample to the set of dispute filings that do not involve China and our results are substantively unchanged. We interpret these results as prima facie evidence that the establishment of affiliates abroad for trade purposes is associated with fewer AD dispute filings, while arm’s-length trade transactions with unaffiliated parties have no meaningful effect.

[Table 2 here]

Our theory suggests that the lower propensity of large firms with international investments to file AD has contributed to the secular decline in filings over time. In columns 4-7 we examine whether large firms with high levels of related-party trade file fewer disputes by including the interaction between Related-party and Sales in the model. The results in model 4 indicate that Related-party Trade is associated with fewer disputes among large firms. The result holds for firms in the manufacturing sector (model 5), and to the set of disputes not involving Chinese firms (model 6). ${ }^{48}$

To facilitate the interpretation of the results, we examine the interaction between a dummy variable indicating positive Related-party Trade, and Sales volume in model 7. We plot the effect of the presence of intrafirm trade on the incidence rate ratio- the rate of incidence of counts among firms with affiliates that trade intrafirm and those without ${ }^{49}$ —of AD filings along

48. The results are consistent when we restrict the sample to China-only filings.

49. To compare the number of filings among firms with intrafirm trade and those without, we compute the incidence rate ratio, which represents the ratio of two ratios: the ratio of firms with intrafirm trade that file and the ratio of firms without intrafirm trade that file. The graph displays the incidence rate ratio at varying levels of firm sales. 
the empirically relevant range of firm Sales. ${ }^{50}$ The figure demonstrates the incidence rate of filings among firms with positive intrafirm trade compared to those with zero intrafirm trade at different levels of sales. As sales increases, the expected number of filings by firms with positive intrafirm trade decreases. The interactive effect becomes statistically significant at around $\$ 1.3$ billion in sales, and firms of this size with positive intrafirm trade file approximately 1-.44 $=56$ percent fewer disputes. At the far right of the size distribution (over $\$ 100$ billion in sales), firms with vertically integrated affiliates file 97 percent fewer disputes.

The evidence is consistent with our argument that increases in the investment by large firms in foreign affiliates for trade lessens demands for temporary trade barriers during an era of currency undervaluation and increased import competition. In decomposing MNC trade flows, we find that intrafirm trade, which indicates ownership of trading affiliates and serves as our main proxy for firm participation in global production activities, is associated with fewer dispute filings. While firms may also engage in global production by trading at arm's-length, we find no evidence that trade with unaffiliated parties is associated with fewer disputes. The results are consistent with the view that vertical FDI by large firms explains the reduction in the number of U.S. trade dispute filings.

50. We find that no U.S. MNCs with sales under \$23M filed AD petitions. We begin the labeling of the $\mathrm{x}$-axis near the point at which the interaction between sales and the dummy for positive intrafirm trade becomes statistically significant. 


\section{Currency Undervaluation and Vertical FDI}

We have established that 1) firms that undertake AD filings were much more internationally engaged than industry peers, but not with the country against which they filed, 2) AD filing firms that survived from 1993 to 2009 partly changed the location of their value chains, and were especially likely to engage in trading, both arm's-length and related-party, with countries against which they and other firms had AD filings, and 3) large firms with intrafirm trade are unlikely to undertake AD filings.

A corollary to these findings is that currency undervaluation is likely to be associated with increased investment by U.S. MNCs in countries with undervalued currencies. We therefore examine whether U.S. multinationals change their investment in countries with undervalued currencies, paying particular attention to affiliates that are vertical (the affiliate exports to the U.S. parent or to other related parties) vs. horizontal (the affiliate does not export). Using detailed sales data from the BEA at the foreign affiliate level, we capture the overall presence of MNC affiliates in foreign countries, as well as the presence of vertical and horizontal affiliates specifically. (See the appendix for details on the method of categorizing the activities of foreign affiliates.)

We link the total number of each affiliate type with our country-level measure of undervaluation to observe changes in investment patterns over the period. Table 3 reports the number of foreign affiliates of U.S. MNCs in each group of countries present in each quinquennial Benchmark Survey conducted by the BEA between 1994 and 2009. ${ }^{51}$ For the

51. We begin with the 1994 Benchmark survey to examine the current era of currency undervaluation characterized most notably by the $50 \%$ depreciation of the Chinese yuan in December of 1993. The undervaluation period is chosen to coincide with the period we analyze 
groups of countries with undervalued and overvalued real exchange rates, we report total affiliates, along with counts of affiliates that export to related parties and those that do not export.

\section{[Table 3 here]}

We compare growth rates of affiliates in countries with undervalued real exchange rates to affiliate growth rates in countries with overvalued real exchange rates. We find that the number of overall affiliates grew by 20\% between 1994 and 2009 in undervalued countries compared to a decline of $20 \%$ over the same period in countries with overvalued currencies.

The key comparison, however, concerns intrafirm exporting affiliates vs. non-exporting affiliates. We observe much larger differences in growth rates for affiliates engaged in intrafirm trade in countries with undervalued exchange rates compared to growth rates of these affiliates in countries with overvalued exchange rates. In particular, we find that the number of affiliates that export to related parties increased by $80 \%$ in countries with undervalued currencies while the number of this type of affiliate declined by $31 \%$ in countries with overvalued exchange rates.

In contrast, we observe little difference in growth rates of non-exporting affiliates in undervalued versus overvalued countries, where the number of affiliates in this category has declined slightly in both sets of countries. If U.S. MNCs were targeting (horizontal) growth opportunities in countries with undervalued currencies, in addition to production cost advantages, we expected to have observed higher growth in the number of non-exporting affiliates than what we do observe.

using the Census LFTTD data, though we obtain consistent results to the inclusion of affiliate data from the 1989 Benchmark survey. 
In Appendix Table A1, we report OLS models of differences in the logged number of affiliates in each category regressed on undervaluation during the prior five year period, and year dummies. In these models, Undervaluation varies at the country-period level. The results are consistent with the descriptive statistics reported here: we find that undervaluation is strongly associated with increases in the number of affiliates that export to related parties, but not with the change in the number of non-exporters. The analysis suggests that MNCs respond to foreign exchange rate undervaluation by setting up vertical affiliates in these countries.

Currency Undervaluation, Trade Flows, and Antidumping Filings at the Country Level

A robust finding in prior political economy research is that, at the country level, currency undervaluations are associated with increased AD filings. An implication of our argument is that the composition of a country's trade with the U.S., especially MNC intrafirm trading, might interact with its currency valuations in influencing U.S. firm AD filings.

To conduct our country level analysis, we link the antidumping petitions to countryspecific variables to generate a unique cross-national time-series dataset that includes a number of theoretically informed country characteristics that vary annually. Subject to data availability, our sample includes all countries in the world for which currency undervaluation data are available. A major advantage of our approach is that our explanatory variables are specific to countries outside the U.S. In contrast to the majority of studies, which model AD filings as a function of filing country and industry characteristics, we match exchange rate, investment and other macroeconomic data to the countries named (and not named) in the AD disputes.

We report the estimates of the country-level determinants of antidumping filings by U.S. firms over either 1982-2011 or 1997-2011. In terms of the dependent variable, we count the 
number of antidumping petitions filed in the U.S. against each country for each year in our sample.

One main independent variable in our analysis captures real currency undervaluation for all countries in our sample. We include indicators of a country's openness to foreign direct investment flows. One is an indicator for capital account openness from Quinn and Toyoda ${ }^{52}$ : countries with open capital accounts have limited capacity to restrict U.S. foreign direct investment, which is likely to lessen antidumping filings. We also include an indicator for whether a country has a bilateral investment treaty with the U.S. We propose that firm investment and trading behaviors will influence antidumping filings, and both capital account openness and a bilateral investment treaty with the U.S. are likely to enable or enhance vertical integration by U.S. firms. We gauge the presence of U.S.-based global production networks by incorporating measures of intrafirm (or related-party) along with arm's-length imports from each country into the U.S. as a share of U.S. GDP, 1996-2010. ${ }^{53}$

We control for a host of variables identified in the literature as correlates of trade disputes and of our main explanatory variables. The Polity 2 index measures democracy: prior studies have found democracy to be a positive correlate of trade disputes; ${ }^{54}$ GDP per capita proxies for

52. Quinn and Toyoda 2008.

53. The trade data are from the Census Bureau's Related Party Trade Database, available at http://sasweb.ssd.census.gov/relatedparty/. We note that the data do not allow us to differentiate between imports by U.S.-based parent firms from affiliates abroad and imports by U.S.-based affiliates from foreign-based parent firms. We thank Kristen Corwin for providing access to the data recording related party trade prior to 2002.

54. Busch 2000; Rosendorff 2005; and Sattler and Bernauer 2011. 
wealth and overall institutional quality, both of which are positive correlates of trade disputes. ${ }^{55}$ In the models where data for U.S. intrafirm trade data are not available, we include a measure of the bilateral trade balance with the U.S. as a share of U.S. GDP, with positive numbers indicating a U.S. trade surplus with the other country.

Since the initiation of an $\mathrm{AD}$ filing requires firms to evaluate the material injury that they have suffered, we expect a non-trivial delay between real exchange rate movements and the dependent variable. We therefore introduce all of our regressors with a one-year lag, except for GDP/capita, which we lag three years in keeping with the estimation choice in Knetter and Prusa and the trade balance, which lag two years. ${ }^{56}$

The yearly count of antidumping disputes, our main dependent variable, ranges from zero to a maximum of 12 . The variable is strongly skewed, with about $85 \%$ of the observations equaling zero, and many countries having no filings against them. (Panel unit root tests, not reported to save space, strongly reject the null of a unit root.) To address overdispersion in the data, we follow the firm-level analysis and estimate a zero-inflated negative binomial model. ${ }^{57}$

The full model estimated for the longest available data is:

55. Knetter and Prusa 2003; Sattler and Bernauer 2011.

56. Knetter and Prusa 2003, 9. The timing of the GDP lag among 1, 2, and 3 lags is not consequential. The trade data are lagged two years owing to missing data for recent period. The timing of the trade balance lag among 1, 2, and 3 lags is not consequential.

57. Copelovitch and Pevehouse 2011 and Sattler and Bernauer 2011 adopt either the same or related approaches in controlling for the ‘excess’ zeros found in bilateral trade disputes data. In this set of regressions, we use trade disputes lagged three years as the predictor for overdispersion since it better predicts overdispersion at the country-level. 


$$
\begin{aligned}
& \text { Disputes }_{i, t}=\beta_{0}+\beta_{1}\left(\text { Disputes }_{i, t-1}\right)+\beta_{2}\left(\text { Undervaluation }_{i, t-1}\right)+\beta_{3}(\text { GDP/Per Capita } i, t-3) \\
& +\beta_{4}\left(\text { Polity }_{i, t-1}\right)+\beta_{5}(\text { Capital Account Openness } i, t-1)+\beta_{6}\left(\text { Bilateral Investment Treaty }_{i, t-1}\right) \\
& +\beta_{7}(\text { Bilateral Trade Balance } i, t-2)+
\end{aligned}
$$


market economy differ from cases involving market economies. ${ }^{58}$ Moreover, the Vuong test suggests that a zero binomial model is inappropriate in analyzing Chinese data. ${ }^{59}$

The results in column 1 suggest that undervaluation is associated with increases in the number of trade disputes, which is similar to prior findings in the literature. In particular, a onestandard deviation increase in undervaluation increases the number of AD filings by about $250 \% .{ }^{60}$ The results are robust to the omission of the lagged endogenous term (column 2).

[Table 4 here]

We find, to our knowledge uniquely, that greater openness to international capital flows and the presence of a bilateral investment treaty with the U.S. are associated with reduced likelihoods of antidumping filings. Both open capital markets and, especially, a bilateral investment treaty enable FDI by U.S. firms in the host country, a point to which we return below. While the control variables are not the main focus we find, consistent with other studies, that U.S. firms are more likely to file antidumping disputes against firms in countries that are more democratic, wealthier, and with whom the U.S. has a trade deficit. ${ }^{61}$ The estimated effects of the

58. See the discussion in Tatelman 2007.

59. Empirically, we find the parameter estimates for China to be quite different from the rest of the sample and this parameter heterogeneity also leads us to present analyses of China separately.

60. The exponentiation of the zero inflated binomial model coefficient gives the increase or decrease in the estimated incidence of $\mathrm{AD}$ filings. For example, the exponentiation of the estimate for undervaluation, 0.817 , equals 2.26 , or a $226 \%$ increase in the incidence.

61. Some scholars have found that trade disputes are largely driven by the steel and metal industries (e.g., Broz and Werfel forthcoming). We explore this finding by restricting the sample 
democracy and capital account variable are very modest, even if statistically significant. The model estimated in column 1 fits the data well. ${ }^{62}$

The results in Table 5 explore the core theory about the relationship between and among undervaluation, trade flows, and trade disputes. Specifically, we examine how related-party import shares (and arm's length import shares) relate to trade disputes in the context of undervalued currencies. The sample is necessarily shorter owing to the unavailability of relatedparty trade data from the U.S. Bureau of the Census before 1996. The model in column 1 in Table 4 is re-estimated on the shorter sample (column 3 in Table 4) to assess whether the parameter estimates differ owing to changes in the length of the sample. The signs, magnitudes,

to non-metal and metal disputes, defined as HS codes 72-83. The relationship between undervaluation and disputes is similar across those subsamples.

62. We examine the predictions of column 1 in Appendix Figure A1, which shows actual trade disputes and the predicted number of trade disputes based on the zero-inflated negative binomial estimates reported in column 1 . Model 1 generates a very close approximation between predicted and observed trade disputes, 1982-2011. One concern, following Bechtel and Leuffen 2010, is that the inclusion of the lagged endogenous variable provides most of the explanatory power. Figure A1 also shows predictions from the results of column 2 in Table 4 (omitting the lagged trade disputes term) and predictions from a model with only the lagged endogenous term included. The model with only the lagged term fares poorly in terms of predictions; the model without the lagged endogenous variable offers a close approximation of the observed filings, though the model including the term is preferred. 
and levels of statistical significance of the parameter estimates are similar between column 1 (1982-2011) and column 3 (1997-2011).

The estimates reported in column 1 of Table 5 indicate that the unconditional relationship between related-party imports is positive: countries from which U.S. intrafirm imports represent a higher share of U.S. GDP are more likely to incur trade disputes. Our theory, however, proposes an interactive effect between intrafirm trade flows and undervaluation. We report interactions between the trade shares and undervaluation in the remaining columns of Table 5 . The results in column 2 (with trade shares and the interactions with undervaluation and column 4 (with full covariates additionally added) are consistent with the hypothesis that firm vertical FDI and subsequent intrafirm trade mediates the relationship between undervaluation and AD dispute filings. In particular, we find that undervaluation increases or decreases the likelihood of trade disputes depending on the composition of imports. Undervaluation is associated with an increased likelihood of antidumping filings against countries from which more arm's-length U.S. imports originate, and with fewer disputes against countries from which U.S. related-party imports represent a greater share of U.S. GDP. The results in column 3 omit the lagged dependent variable, and these results change very little.

A concern could be that many U.S. firms undertake arm's-length trading as part of their value chain activities such that the data for arm's-length trading will include information about MNC value chains. In column 5, we report the results of a model in which we extracted predicted values of related-party trading in a first stage model. ${ }^{63}$ The data for arm's-length trade

63. Prior research has shown that arm's length trade and related party trade are highly correlated at the firm level. (Bernard et al. 2009; Ramondo, Rappaport, and Ruhl 2013.) We also know, as a near accounting identity, that related party trading follows from prior FDI in the country in 
and the predicted value of related-party trade flows are essentially uncorrelated. The coefficient estimates for the main explanatory variables maintain (or increase) their levels of statistical significance. The exception is undervaluation, which now has a positive and statistically significant coefficient estimate. In column 6, we substitute U.S. inward FDI for related-party trade under the assumption that FDI precedes U.S. intrafirm imports. The intuition is that relatedparty imports arise from either U.S. foreign direct investment in the host country or foreign direct investment in the U.S. We find that arm's-length trading is only modestly correlated with FDI. Our results indicate that FDI lessens trade disputes in the context of undervaluation, controlling for the effects of arm's-length imports into the U.S. In sum, our results are consistent with the view that firm vertical FDI and intrafirm trade flows decrease AD filings in the context of undervaluation.

As we note above, China is likely to be an unusual case, both because of its special status under U.S. trade law and because of the large effects its economic activities have on the U.S. market. ${ }^{64}$ We investigate the China case explicitly and report the results in Table 6. The results indicate that increased arm's-length imports from China are associated with increases in trade disputes, while related-party imports are strongly negatively correlated with filings. Figure 8 shows that the predictions from our model match closely the number and timing of actual

question. We therefore estimate a model of a country's likely related party trade with the U.S. from a model including lagged arm's length trading, prior FDI, and the country's national per capita income. The details of the first stage are available upon request.

64. See Autor, Dorn, and Hanson 2013 for a discussion of the magnitude effects on Chinese import competition of U.S labor markets. 
antidumping petitions by U.S. firms against China.

\section{Conclusion}

A new wave of scholarship in international trade has shown that firm-level heterogeneity within an industry is a main driver of trade and international investment activities. We propose that firm-level heterogeneity in investment and trade has political implications for firm and industry political and regulatory activities. We use U.S. firm AD filings as a prism to explore this proposition. We argue that the specific locations of firm vertical foreign direct investments and the resulting related-party trading help explain the recent decline in firm AD filings, and we use both micro-level firm and macro-level national data to examine our claims.

Using micro data, we identify the characteristics of filers and non-filers. Firms that file for trade remedies are much larger in terms of employment (and sales) than are their industry peers, and are more internationally engaged in imports and exports than the median firm in their industries. Where they differ from their peers is in their FDI and related-party trading activities, particularly in countries against whose firms they file. Filing firms are generally not internationally engaged with countries against whose firms they file. Under a regression framework, we find more generally that intrafirm trade conducted with global affiliates, especially for large U.S. MNCs, sharply reduces the number of AD filings.

An important corollary to our argument is that firms will respond to the economic incentives to invest in countries with undervalued currencies for trade-related production activities. We find preliminary evidence that currency undervaluation is associated with increases in the number of MNC affiliates in a country, particularly for foreign affiliates that export to related parties. 
We also document the hypothesized negative relationship between related-party trade and antidumping disputes in the context of bilateral undervaluation and increasing import competition using national-level data. Extending existing research, we find that the effects of bilateral currency undervaluation on antidumping filings are a non-linear function of the levels of related-party trade. High levels of related-party trading sharply diminish the likelihood of trade disputes with the U.S. in the presence of undervaluation.

Our paper contributes to the literature by demonstrating that the specific location and nature of firm international engagement explains firm political and economic responses to trade competition. Once firms have investment or trade positions in countries, particularly once they set up vertical affiliates with which they trade, trade disputes become less likely, even in the context of currency undervaluation and rising import competition. The rising share of economic activity accounted for by firms with global production affiliates in countries with undervalued currencies makes organizing a coalition representing 25 percent of activity in a product market increasingly difficult. Given the rapid expansion of global supply chains, our findings offer a partial explanation for the decline in antidumping filings and a puzzling dearth of protectionism in the wake of the Global Financial Crisis. The current round of semi-competitive 'currency undervaluations' need not lead to increased trade disputes. 


\section{Data Appendix}

\section{Antidumping Petition Data}

Our data source for AD petitions is the May 2012 update of the Global Antidumping Database (GAD-USA.xls - Bown 2012). Coverage includes all antidumping petitions filed in the U.S. since 1980, including the name of the petitioner, a detailed product code corresponding to the product(s) under investigation, the country host of the firm against which the dispute is filed, and the date of the initiation of the investigation. ${ }^{65}$

\section{Firm and Intra-Industry Level International Engagement Data}

To examine the behavior of individual firms in an industry context, we use the U.S. Linked/Longitudinal Firm Trade Transaction Database (LFTTD), which links individual U.S. trade transactions to U.S. firms using a longitudinal database of U.S. enterprises that tracks almost all private sector firms in the United States. ${ }^{66}$ For each export and import transaction, we observe the ten-digit Harmonized System classification, the (nominal) value and quantity shipped, the shipment date, the destination or source country, the transport mode, and whether the transaction takes place at “arm’s-length” or between "related-parties”. Export partners are “related” if either party owns, directly or indirectly, 10 percent or more of the other party. For imports, the ownership cutoff is 6 percent.

We match the antidumping firm filings data compiled by Bown (2012) to the Census Bureau's Business Register using the name of the filing organization. (Some of the filers are not

65. The GAD lists data from 1980 onward as being available, although data for 1979 for the U.S. are available in the file.

66. For more information on the LFTTD, see Bernard, Jensen, and Schott 2009. 
firms; filing organizations include, e.g., labor organizations, farm produce coops, and cities.) Once the antidumping filing firms are matched to the Business Register, we use a common identifier to match to the LFTTD and the Census Bureau’s Longitudinal Business Database (LBD). The LBD contains information on industry and employment for almost all private sector establishments in the U.S. ${ }^{67}$ The combination of the LBD and the LFTTD allow us to construct a detailed and comprehensive picture of U.S. firms' domestic operations and international trade relationships.

We classify firms into product markets based on the 6-digit NAICS industry in which the firm is active and in which it has the most employment (using information from the Census Bureau's Longitudinal Business Database) for each year. ${ }^{68}$ All firms are classified into a single 6-digit industry and we restrict the sample to the manufacturing sector.

67. See Jarmin and Miranda 2002.

68. The North American Industrial Classification System (NAICS) is used to classify producers based on the production technology used in the establishment. The Harmonized System (HS) is used to classify products in international trade. Unfortunately, the two systems are distinct systems with little structural similarity. We classify firms at the 6-digit NAICS level to obtain fairly narrow company comparisons. We compare imports and exports of products at the 4-digit level as this is the level AD filing data are most detailed and still reliable. 


\section{U.S. Multinational Company Data}

We rely on confidential firm-level data from the Bureau of Economic Analysis (BEA) quinquennial Benchmark Surveys of U.S. Direct Investment Abroad. A U.S. multinational company consists of a U.S. parent (headquarters) company and each of its foreign affiliates. ${ }^{69}$

Our analysis of firm responses to undervaluation uses affiliate-level data from the 1994, 1999, 2004, and 2009 benchmark surveys. ${ }^{70}$ The affiliate-level data allow us to decompose affiliate sales to a variety of buyers, including the U.S. parent, the host country, and other foreign affiliates $^{71}$ to generate the following sums:

- Total affiliates: the total number of affiliates of U.S. MNCs

- Related-party exporters: the total number of affiliates that export to the U.S. parent or to other foreign affiliates (vertical affiliates)

- Non-exporters: the total number of affiliates that do not report positive exports (horizontal affiliates)

69. Any U.S. person with direct or indirect ownership of ten percent or more of the voting securities of a foreign business during the benchmark fiscal year is a U.S. parent of the foreign business, which is termed its foreign affiliate..

70. We rely on the responses from surveys accepted by the BEA and exclude those that were not accepted due to reporting errors.

71. The data on foreign affiliate sales broken down by destination are collected for majorityowned affiliates only. 
Computing Undervaluation vis-à-vis the U.S.

The real exchange rate can be thought of as the price of tradables relative to nontradables. Our bilateral real exchange rate index captures the unique yearly value of a country's goods, relative to those in the U.S. at the prevailing nominal exchange rate. To generate our index, we rely on price level data from the Penn World Tables 7.1 (Heston et al. 2012). In particular, we compute: 
countries are affected by the tax allocation strategies of multinational companies as much or more than the economic fundamentals of those countries. ${ }^{73}$

Currency Undervaluation and MNC Investment

In Appendix Table A1, we report regression estimates of changes in the number of affiliates. We include currency undervaluation in the host country as the explanatory variable. Specifically, we estimate the following model using ordinary least squares: 


\section{References}

Autor, David H., David Dorn, and Gordon H. Hanson. 2013. The China Syndrome: Local Labor Market Effects of Import Competition in the United States. American Economic Review. Accessed at: http://irps.ucsd.edu/assets/001/504178.pdf.

Bechtel, Michael M., and Thomas Sattler. Forthcoming. What is Litigation in the World Trade Organization Worth? International Organization.

Bechtel, Michael M., and Dirk Leuffen. 2010. Forecasting European Union Politics: Real-time Forecasts in Political Time Series Analysis. European Union Politics 11(2):309-327.

Bernard, Andrew B., and J. Bradford Jensen. 1995. Exporters, Jobs, and Wages in U.S. Manufacturing: 1976-87. Brookings Papers on Economic Activity: Microeconomics 1995: 67-119.

Bernard, A. B., and J. B. Jensen. 1999. Exceptional Exporter Performance: Cause, Effect, or Both? Journal of International Economics 47(1):1-25.

Bernard, A. B., J. B. Jensen, S. Redding, and P. Schott. 2007. Firms in International Trade. Journal of Economic Perspectives 21(3): 105-130.

Bernard, A. B., J. B. Jensen, and P. Schott. 2009. Importers, Exporters and Multinationals: A Portrait of Firms in the U.S. that Trade Goods. In Producer Dynamics: New Evidence from Micro Data, T. Dunne, J.B. Jensen, and M.J. Roberts, eds. Chicago: University of Chicago Press.

Blonigen, Bruce A., 1997. Firm-Specific Assets and the Link between Exchange Rates and Foreign Direct Investment. American Economic Review 87(3): 447-465.

Bown, Chad P. 2011. Taking Stock of Antidumping, Safeguards and Countervailing Duties, 1990-2009. The World Economy 34(12): 1955-1998. 
Bown, Chad P. 2011. Introduction. In The Great Recession and Import Protection: The Role of Temporary Trade Barriers. Edited by Chad P. Bown. London, UK: CEPR and the World Bank.

Bown, Chad P. 2012. Global Antidumping Database, Available at $<\underline{\text { http://econ.worldbank.org/ttbd/gad/> }}$

Bown, Chad P., and Meredith A. Crowley. 2012. Import Protection, Business Cycles, and Exchange Rates: Evidence from the Great Recession, Journal of International Economics 90(1): 50-64.

Broz, Lawrence, and Stephen Werfel. Forthcoming. Exchange Rates and Industry Demands for Trade Protection. International Organization.

Busch, Marc L. 2000. Democracy, Consultation, and the Paneling of Disputes under GATT. Journal of Conflict Resolution 44(4):425-446.

Chiquiar, Daniel, Manuel Ramos-Francia, Nicolas Amoroso, and Nuria Quella. 2008. Determinants of Mexico's Comparative Advantages and of the Performance of its Manufacturing Exports During 1996-2005. SSRN Paper \#1638889.

Copelovitch, Mark S., and Jon C. Pevehouse. 2011. Currency Wars by Other Means? Exchange Rates and WTO Dispute Initiation. Paper presented at the 2010 IPES conference.

Copelovitch, Mark S., and Jon C. Pevehouse. 2013. Ties that Bind? Preferential Trade Agreements and Exchange Rate Policy Choices. International Studies Quarterly. 57(2):385-399.

Easterly, William. 2005. National Policies and Economic Growth: A Reappraisal. In Handbook of Economic Growth. Edited by Philippe Aghion and Steven Durlauf. Cambridge MA: Harvard University Press. 
Fischer, S. 1993. The Role of Macroeconomic Factors in Growth. Journal of Monetary Economics 32(3): 485-512.

Froot, K. A., and J. Stein. 1991. Exchange Rates and Foreign Direct Investment: An Imperfect Capital Markets Approach. Quarterly Journal of Economics 106(4): 1191-1217.

Gawande, Kishore, Bernard Hoekman, and Yue Cui. 2013. Global Supply Chains and Trade Policy Responses to the 2008 Crisis. Texas A\&M Typescript Manuscript.

Gravelle, Jane G. 2013. “Tax Havens: International Tax Avoidance and Evasion.” CRS Report for Congress, \#R40623.

Greir, Kevin B., Michael C. Munger, and Brian E. Roberts. 1994. The Determinants of Industry Political Activity, 1978-86. American Political Science Review 88(4):911-926.

Hanson, Gordon H., Raymond J. Mataloni, and Matthew J. Slaughter. 2005. Vertical Production Networks in Multinational Firms, The Review of Economics and Statistics, 87(4): 664678.

Helpman, Elhanan. 1984. A Simple Theory of International Trade with Multinational Corporations. Journal of Political Economy 92 (3): 451-471.

Helpman, Elhanan, Marc J. Melitz, and S. R. Yeaple. 2004. Export versus FDI with Heterogeneous Firms. American Economic Review 94(1): 300-316.

Heston, Alan, Robert Summers and Bettina Aten. 2012. Penn World Table Version 7.1. Center for International Comparisons of Production, Income and Prices at the University of Pennsylvania URL < $\underline{\text { http://pwt.econ.upenn.edu/> }}$

Hilbe, J. M. 2011. Negative Binomial Regression. New York: Cambridge University Press. Hiscox, Michael J. 2001. Class versus Industry Cleavages: Inter-Industry Factor Mobility and the Politics of Trade International Organization 55(1):1-46. 
International Monetary Fund. 2012. External Balance Assessment (EBA): Technical Background of the Pilot Methodology. Accessed at http://www.imf.org/external/np/res/eba/pdf/080312.pdf.

Irwin, Douglas. 2005. The Rise of U.S. Antidumping Activity in Historical Perspective. The World Economy 28(5):651-668.

Jarmin, R.S., and J. Miranda. 2002. The Longitudinal Business Database, Working Papers 02-17, Center for Economic Studies, U.S. Census Bureau.

Jensen, Nathan M. 2013. Domestic Institutions and the Taxing of Multinational Corporations. International Studies Quarterly 57(3): 440-448.

Knetter, Michael, and Thomas J. Prusa. 2003. Macroeconomic Factors and Anti-dumping Filings. Journal of International Economics 61(1): 1-18.

Lane, Philip R., and Gian-Maria Milessi-Ferretti. 2007. The External Wealth of Nations, Mark II: Revised and Extended Estimates of Foreign Assets and Liabilities. 1970-2004. Journal of International Economics 73: 223-250.

Ludema, Rodney, and Anna-Maria Mayda. 2011. Canada: No Place Like Home for Antidumping. In The Great Recession and Import Protection: The Role of Temporary Trade Barriers. Edited by Chad P. Bown. London, UK: CEPR and the World Bank. Magee, Stephen P. 1980. Three Simple Tests of the Stolper-Samuelson Theorem, in Issues In International Economics, Peter Oppenheimer (ed.). London: Oriel Press: 138-153.

Mansfield, Edward D., and Marc L. Busch. 1995. The Political Economy of Nontariff Barriers: A Cross-national Analysis. International Organization 49(4):723-723. 
Melitz, Marc J. 2003. The Impact of Trade on Intra-Industry Reallocations and Aggregate Industry Productivity. Econometrica 71(6): 1695-1725.

Messerlin, P.A. 2004. China in the World Trade Organization: Antidumping and Safeguards. The World Bank Economic Review 18(1):105-130.

Milner, Helen. 1988. Trading Places: Industries for Free Trade. World Politics 40(3): 350-376.

Morrison, Wayne M., and Marc Labonte. 2008. China’s Currency: Economic Issues and Options for U.S. Trade Policy. CRS Report for Congress \#RL32165.

Oatley, Thomas. 2010. Real Exchange Rates and Trade Protectionism. Business and Politics 12(2): $1-17$.

Page, John. 1994. The East Asian Miracle: Four Lessons for Development Policy. In NBER Macroeconomics Annual 1994. Edited by Stanley Fischer and Julio J. Rotemberg. Cambridge: MIT Press.

Pierce, Justin R. 2011. Plant-Level Responses to Antidumping Duties: Evidence from U.S. Manufacturers. Journal of International Economics 85(2): 222-233.

Prusa, Thomas J., and Edwin Vermulst. 2013. United States - Definitive Antidumping and Countervailing Duties on Certain Products from China: Passing the Buck on PassThrough. World Trade Review 12(2):197-234.

Quinn, Dennis P. and A. Maria Toyoda. 2008. Does Capital Account Liberalization Lead to Economic Growth? Review of Financial Studies. 21(3):1403-1449.

Ramondo, Natalia, Veronica Rappoport, and Kim J. Ruhl. 2013. Horizontal Versus Vertical Foreign Direct Investment: Evidence from U.S. Multinationals. UC San Diego Typescript Manuscript. 
Rosendorff, B. Peter. 2005. Stability and Rigidity: Politics and Design of the WTO’s Dispute Settlement Procedure. American Political Science Review 99(3):389-400.

Rogowski, Ronald. 1987. Political Cleavages and Changing Exposure to Trade. American Political Science Review 81(4): 1121-1137.

Rodrik, Dani. 2008. The Real Exchange Rate and Economic Growth. Brookings Papers on Economic Activity 2008(2): 365-412.

Ruhl, Kim J. 2013. An Overview of U.S. Intrafirm-Trade Data Sources. New York University Typescript Manuscript.

Rumbaugh, T., and N. Blancher. 2004. China: International Trade and WTO Accession IMF Working Paper \#04-36.

Sanford, Jonathan E. 2011. Currency Manipulation: The IMF and the WTO. CRS Report for Congress, \#22658.

Sattler, Thomas, and Thomas Bernauer. 2011. Gravitation or Discrimination? Determinants of Litigation in the World Trade Organization. European Journal of Political Research 50(2):143-167.

Tatelman, Todd B. 2007. United States’ Trade Remedy Laws and Non-Market Economies: A Legal Overview. CRS Report for Congress, RL33976.

Tomiura, Eiichi. 2007. Foreign Outsourcing, Exporting, and FDI: A Productivity Comparison at the Firm Level. Journal of International Economics 72 (1), 113-127.

Villarreal, M. Angeles. 2012 Mexico’s Free Trade Agreements. Congressional Research Service Report \#R40784.

World Bank. 1993. The East Asian Miracle. Washington, D.C.: Policy Research Department. 
World Bank. 2012. Doing Business in a More Transparent World: Comparing Regulation for Domestic Firms in 183 Economies. Washington, DC: World Bank Group.

Yeaple, Stephen Ross. 2009. Firm heterogeneity and the structure of U.S. multinational activity. Journal of International Economics 78(2): 206-215. 


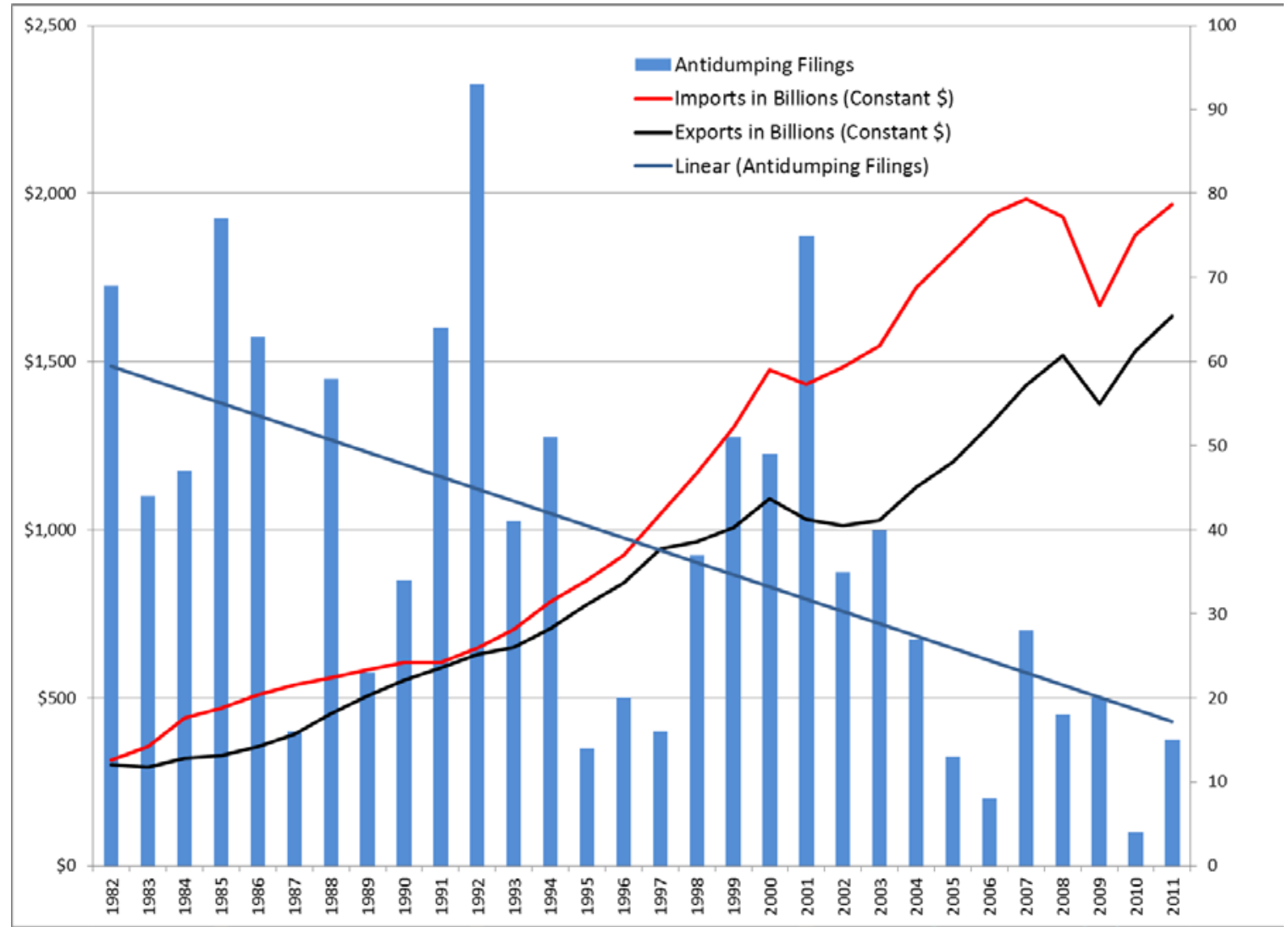

FIGURE 1. Imports, Exports and Total Antidumping Filings by Firms in the U.S., 1982-2011 


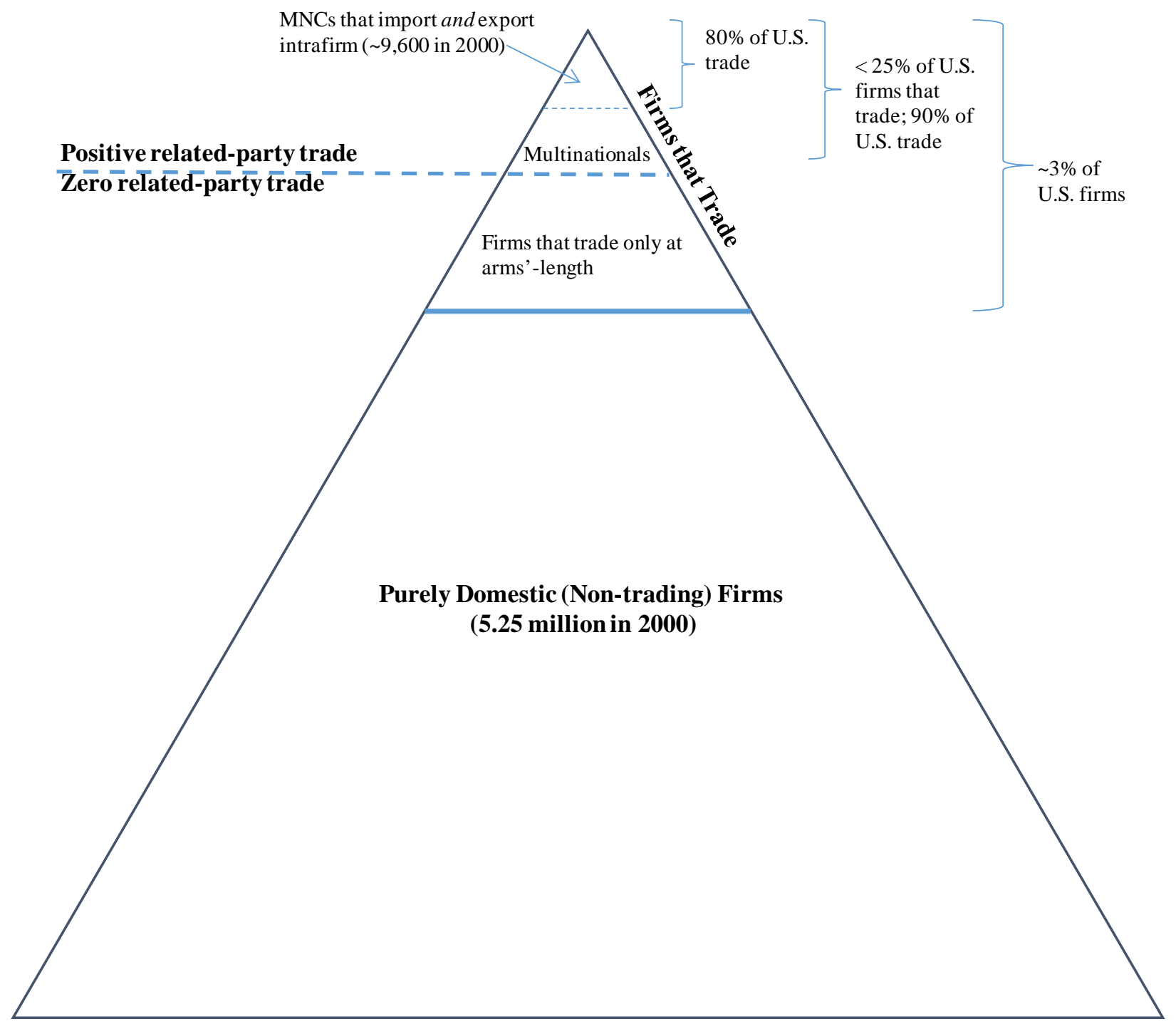

Adapted from Bernard et al. (2009)

FIGURE 2. Firm Heterogeneity in International Engagement 


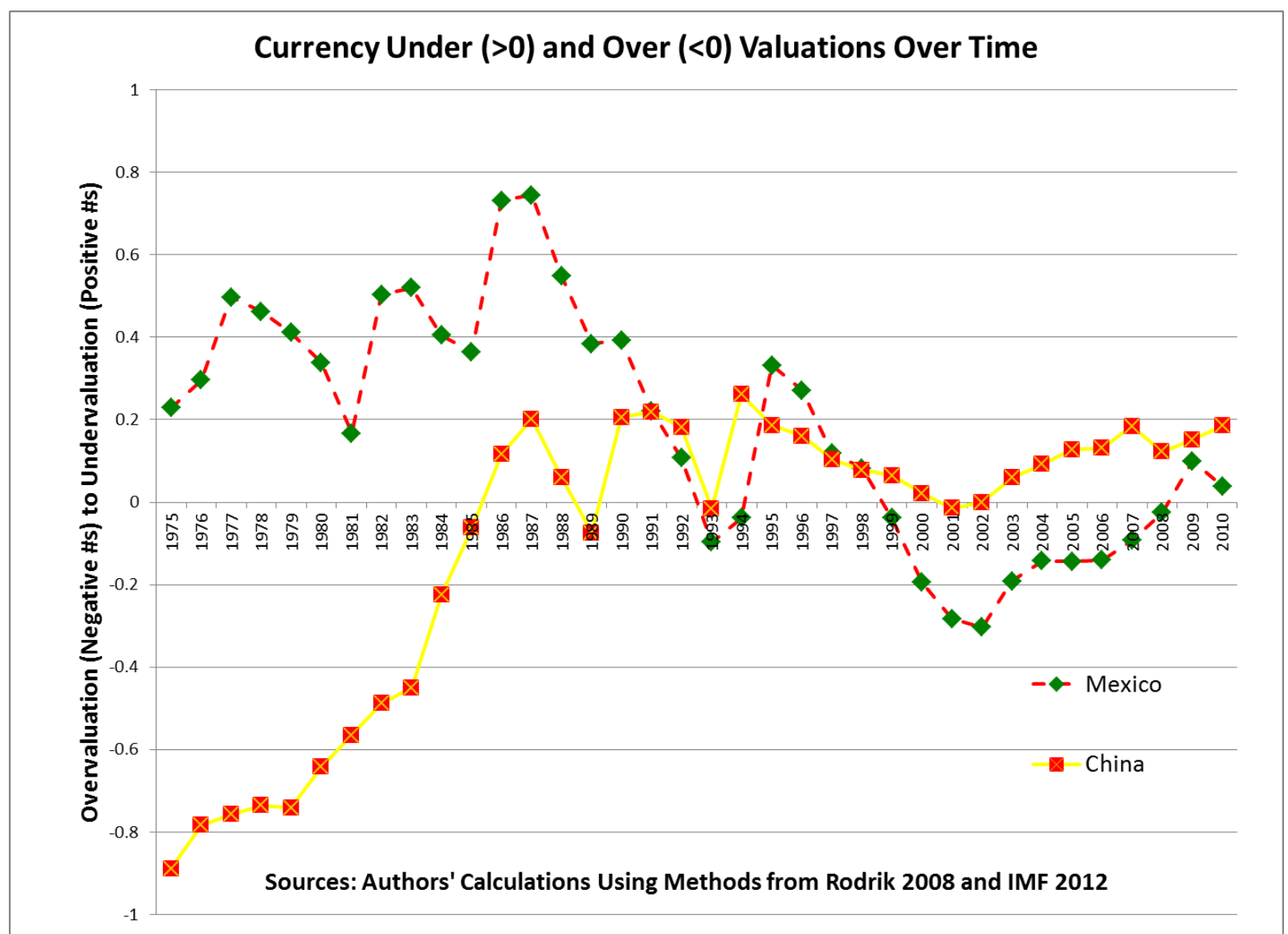

FIGURE 3. Real Exchange Rates of Mexican Peso and Chinese Yuan Relative to the U.S. Dollar, 1975-2010. 


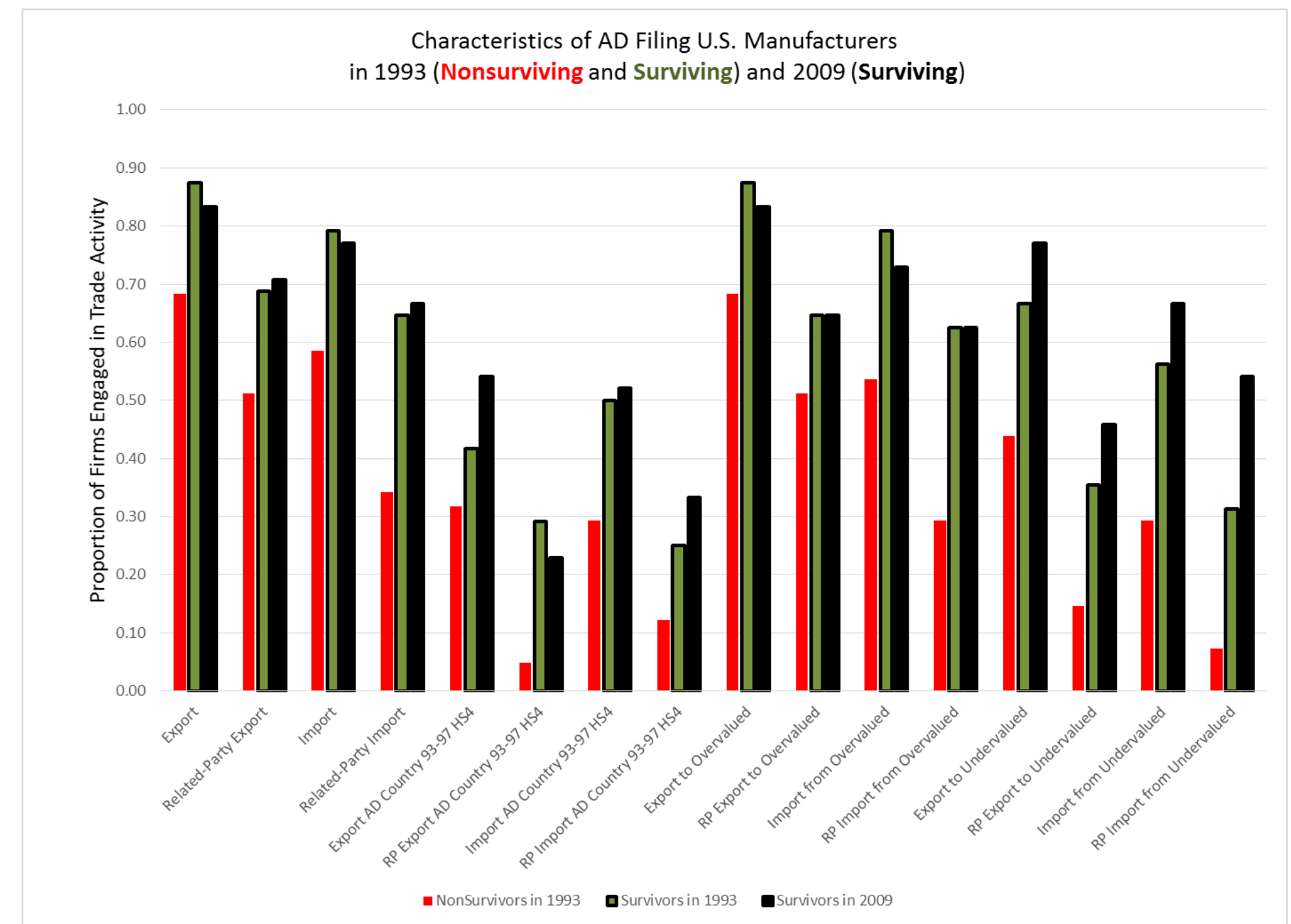

FIGURE 4. Proportion of Firms Filing Antidumping Petitions 1993-1997 Engaging in International Trade Activities of Various Types: Non-Survivors (41) in 1993 and Survivors (48) in 1993 and 2009 


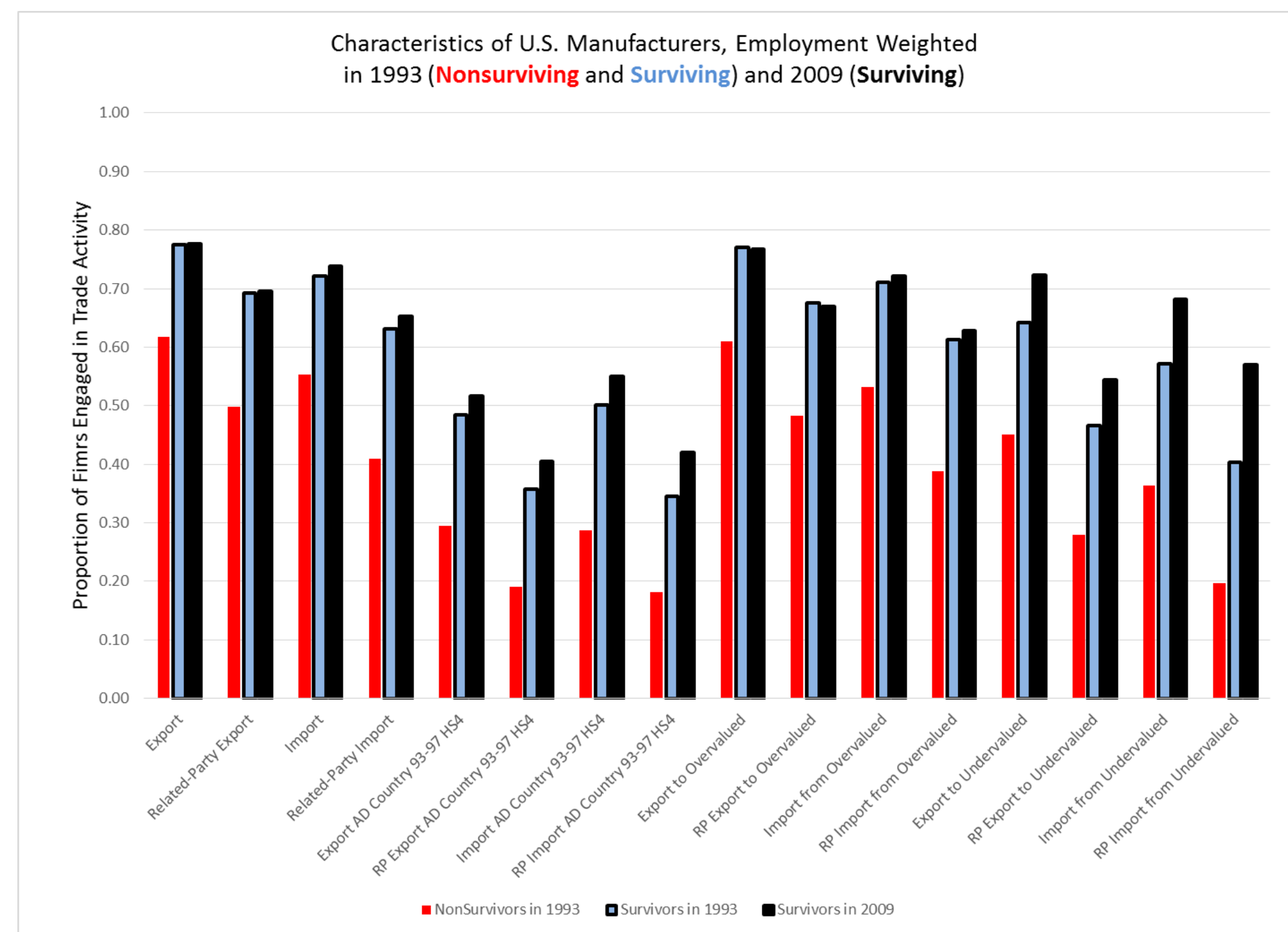

FIGURE 5. Proportion of Manufacturing Firms Engaging in International Trade Activities of Various Types: Non-Survivors $(206,200)$ in 1993 and Survivors (88,800) in 1993 and 2009. Weighted by Employment as a Proxy for Market Share. 


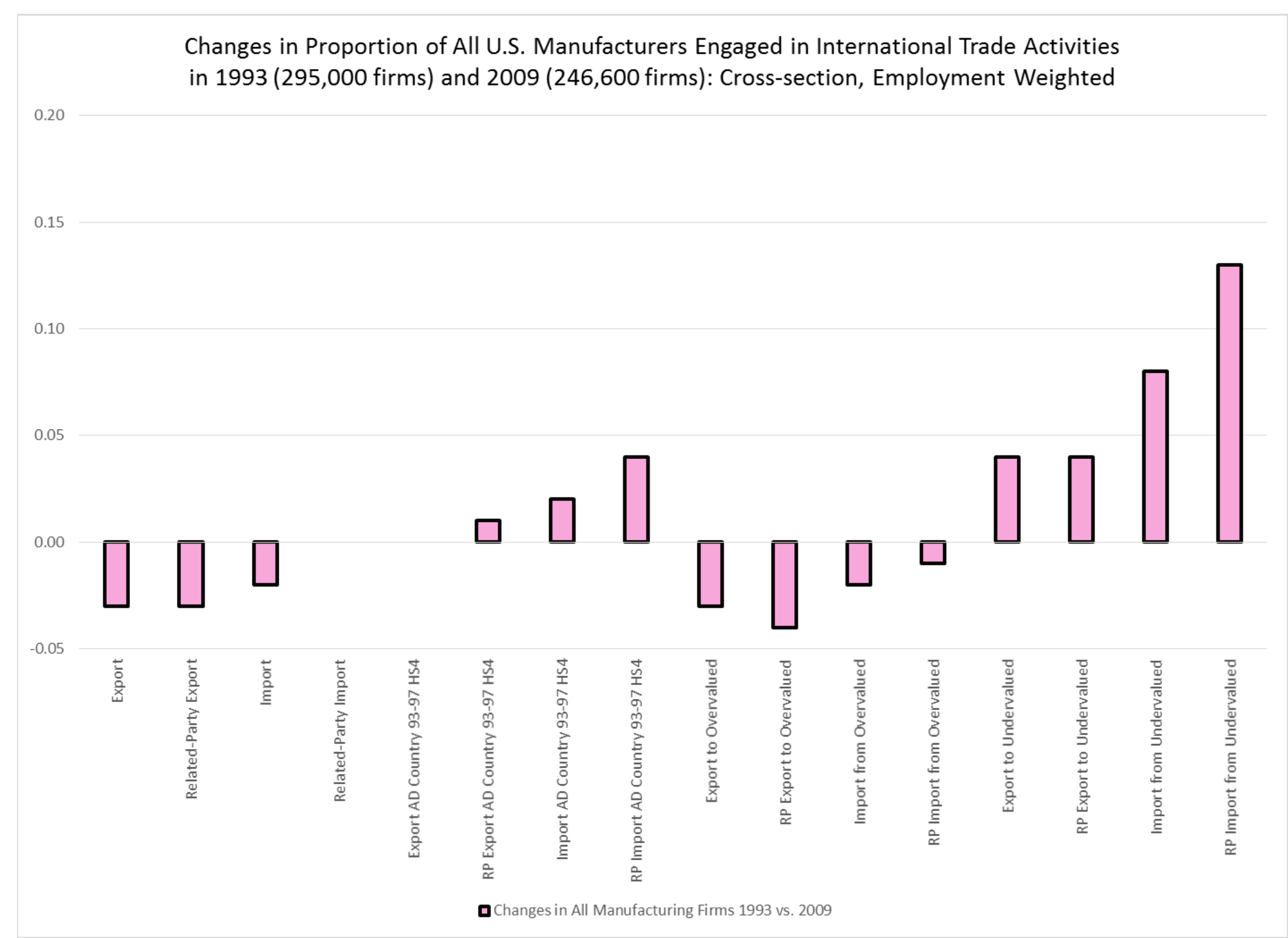

FIGURE 6. Change in Proportion of All Manufacturing Firms Engaging in International Trade Activities of Various Types: All Firms $(295,000)$ in 1993 and All Firms (246,000) in 2009. Weighted by Employment as a Proxy for Market Share. 


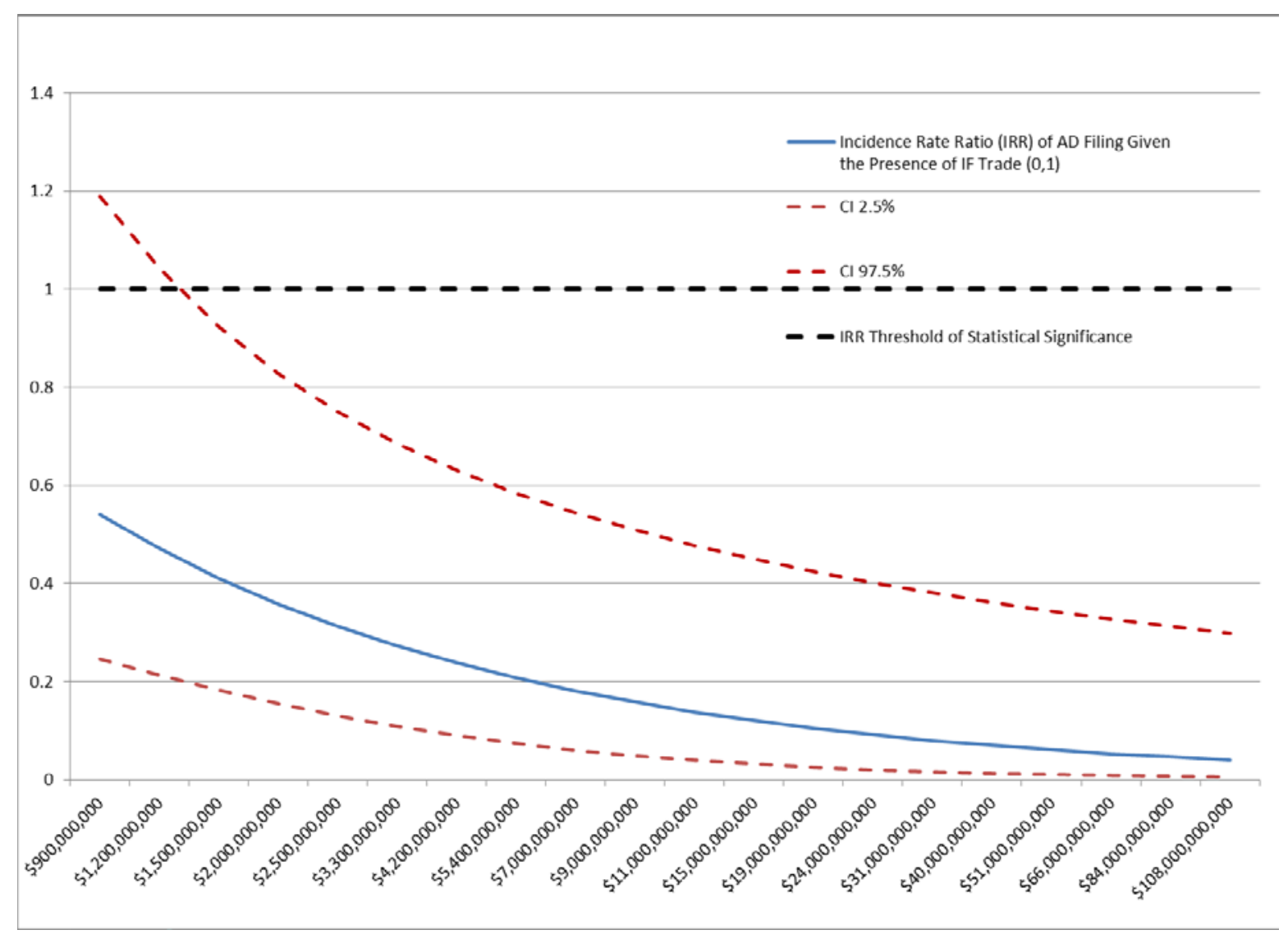

FIGURE 7. Incidence Rate Ratio of Positive Intrafirm Trade on AD Filings Conditioned by Firm Size (Measured by Sales). 


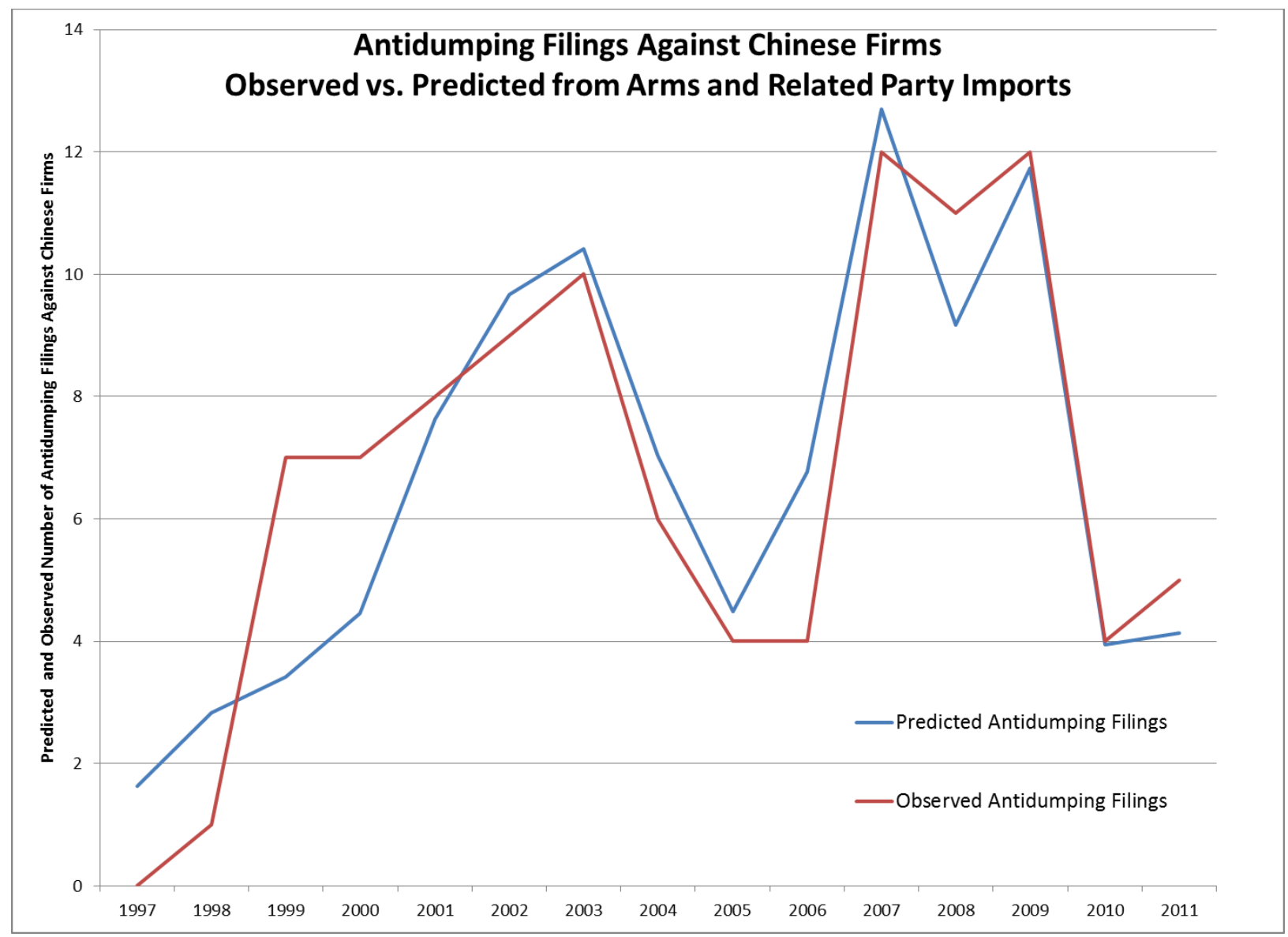

FIGURE 8. U.S. Antidumping Filings Against China. Observed and Predicated. (Derived from results in model 3, Table 8 ) 
TABLE 1. Filer Characteristics at Date of Filing (Pooled, 1993-2009)

\begin{tabular}{|c|c|c|c|c|c|}
\hline & \multirow[b]{2}{*}{$\mathrm{N}=425$} & \multicolumn{2}{|c|}{$\begin{array}{c}\text { Percent Engaging in } \\
\text { Activity at Time of } \\
\text { Filing }(0,1)\end{array}$} & \multicolumn{2}{|c|}{$\begin{array}{l}\text { Percentile Rank } \\
\text { within Industry } \\
\text { (of value) }\end{array}$} \\
\hline & & Mean/\% & Std Dev & & Std Dev \\
\hline 1. & Employment* & 5,871 & 12,860 & 0.88 & 0.19 \\
\hline 2. & Export & $75 \%$ & & 0.74 & 0.38 \\
\hline 3. & Import & $68 \%$ & & 0.68 & 0.42 \\
\hline 4. & Related-Party (RP) Export & $59 \%$ & & 0.61 & 0.45 \\
\hline 5 . & Related-Party (RP) Import & $52 \%$ & & 0.55 & 0.46 \\
\hline 6 & $\begin{array}{l}\text { Export to Contemporaneous AD country in } \\
\text { same HS4 product }\end{array}$ & $29 \%$ & & 0.36 & 0.45 \\
\hline & $\begin{array}{l}\text { Import from Contemporaneous AD country } \\
\text { in same HS4 product }\end{array}$ & $25 \%$ & & 0.33 & 0.44 \\
\hline 8. & $\begin{array}{l}\text { RP Export to Contemporaneous AD country } \\
\text { in same HS4 product }\end{array}$ & $12 \%$ & & 0.21 & 0.37 \\
\hline & $\begin{array}{l}\text { RP Import from Contemporaneous AD } \\
\text { country in same HS4 product }\end{array}$ & $12 \%$ & & 0.21 & 0.38 \\
\hline
\end{tabular}

Note: This table presents statistics for firms that filed AD petitions over the period 1993-2009. The table reports the firms' average rank within their 6-digit NAICS industry and the share of firms engaging in a particular form of international trade. The table reports the share of firms exporting, importing, exporting to a related-party, importing from a related party, and those that engage in exporting/importing/RP exporting/RP importing the same HS4 product category with a country that is filed against. The percentile rank column reports the average of the firms' rank within their industries for the value of these trade volumes. 
TABLE 2. Related-party Trade and MNC AD Dispute Filings, 1989-2009.

\begin{tabular}{|c|c|c|c|c|c|c|c|}
\hline & (1) & $(2)$ & (3) & (4) & (5) & $(6)$ & (7) \\
\hline & Baseline & $\begin{array}{l}\text { Sales, } \\
\text { Sector FE }\end{array}$ & $\begin{array}{l}\text { Non-China } \\
\text { Filings }\end{array}$ & $\begin{array}{c}\text { Sales } \\
\text { Interaction }\end{array}$ & $\begin{array}{c}\text { Manuf. } \\
\text { Only }\end{array}$ & $\begin{array}{r}\text { Interaction, } \\
\text { non-China }\end{array}$ & $\begin{array}{l}\text { Intrafirm } \\
\text { Dummy }\end{array}$ \\
\hline Related-Party ("Intrafirm") Trade & $\begin{array}{c}-0.105^{* * *} \\
(0.031)\end{array}$ & $\begin{array}{c}-0.111^{* * *} \\
(0.032)\end{array}$ & $\begin{array}{c}-0.167 * * * \\
(0.056)\end{array}$ & $\begin{array}{c}0.655^{* *} \\
(0.268)\end{array}$ & $\begin{array}{c}0.967 * * * \\
(0.292)\end{array}$ & $\begin{array}{c}0.887^{* *} \\
(0.378)\end{array}$ & \\
\hline Arms'-Length ("Unaffiliated") Trade & $\begin{array}{c}0.082 * * \\
(0.042)\end{array}$ & $\begin{array}{c}0.011 \\
(0.049)\end{array}$ & $\begin{array}{c}0.009 \\
(0.061)\end{array}$ & $\begin{array}{c}0.029 \\
(0.051)\end{array}$ & $\begin{array}{c}0.043 \\
(0.062)\end{array}$ & $\begin{array}{c}0.010 \\
(0.061)\end{array}$ & $\begin{array}{c}0.029 \\
(0.046)\end{array}$ \\
\hline Sales & & $\begin{array}{c}0.596 * * * \\
(0.113)\end{array}$ & $\begin{array}{c}0.304 \\
(0.384)\end{array}$ & $\begin{array}{c}1.056 * * * \\
(0.203)\end{array}$ & $\begin{array}{c}1.449 * * * \\
(0.240)\end{array}$ & $\begin{array}{c}1.131 * * \\
(0.461)\end{array}$ & $\begin{array}{c}1.020 * * * \\
(0.187)\end{array}$ \\
\hline RP Trade X Sales & & & & $\begin{array}{c}-0.054^{* * *} \\
(0.019)\end{array}$ & $\begin{array}{c}-0.080^{* * *} \\
(0.021)\end{array}$ & $\begin{array}{c}-0.075^{* * *} \\
(0.028)\end{array}$ & \\
\hline $\begin{array}{l}\text { RP Trade Dummy } \\
\qquad \text { (1 if RP Trade is positive) }\end{array}$ & & & & & & & $\begin{array}{l}6.878^{* *} \\
(2.759)\end{array}$ \\
\hline RP Trade Dummy X Sales & & & & & & & $\begin{array}{c}-0.545^{* * *} \\
(0.198)\end{array}$ \\
\hline Constant & $\begin{array}{c}0.517 \\
(0.749)\end{array}$ & $\begin{array}{c}-9.670 * * * \\
(2.334)\end{array}$ & $\begin{array}{l}-3.111 \\
(7.259)\end{array}$ & $\begin{array}{c}-15.849 * * * \\
(3.246)\end{array}$ & $\begin{array}{c}-19.589 * * * \\
(3.591)\end{array}$ & $\begin{array}{c}-14.484^{*} \\
(7.411)\end{array}$ & $\begin{array}{c}-16.067 * * * \\
(2.876)\end{array}$ \\
\hline \multicolumn{8}{|l|}{ Model of Excess Zeros } \\
\hline Total Trade & $\begin{array}{c}-0.352 * * * \\
(0.064) \\
\end{array}$ & $\begin{array}{c}-0.248 * * * \\
(0.074) \\
\end{array}$ & $\begin{array}{c}-0.417 * * \\
(0.204) \\
\end{array}$ & $\begin{array}{c}-0.222^{* * *} \\
(0.061) \\
\end{array}$ & $\begin{array}{c}-0.157^{*} \\
(0.082)\end{array}$ & $\begin{array}{c}-0.348 * * \\
(0.145)\end{array}$ & $\begin{array}{c}-0.229 * * * \\
(0.068) \\
\end{array}$ \\
\hline Year FE & $\mathrm{Y}$ & $\mathrm{Y}$ & $\mathrm{Y}$ & $\mathrm{Y}$ & $\mathrm{Y}$ & $\mathrm{Y}$ & $\mathrm{Y}$ \\
\hline Sector FE & $\mathrm{N}$ & $\mathrm{Y}$ & $\mathrm{Y}$ & $\mathrm{Y}$ & $\mathrm{N}$ & $\mathrm{Y}$ & $\mathrm{Y}$ \\
\hline Observations & 12656 & 12656 & 12608 & 12656 & 6835 & 12608 & 12656 \\
\hline Log-likelihood & -749.0 & -730.9 & -405.2 & -727.9 & -618.7 & -403.0 & -731.9 \\
\hline
\end{tabular}

Note: The table reports the results of zero-inflated negative binomial models of the number of antidumping petitions filed by U.S. multinational corporations, 1989-2009. The variables are all measured at the level of the MNC. The values of Related-Party Trade, Arm's-Length Trade, Sales, and Total Trade represent the natural log transformations of the reported value (plus one). The sector fixed effects correspond to the following categories: construction; agriculture and mining; manufacturing; telecommunications and utilities; wholesale and retail; and services. 
TABLE 3. Undervaluation and MNC Investment (Results based on Data from Bureau of Economic Analysis)

\begin{tabular}{|c|c|c|c|c|c|c|c|}
\hline \multirow{3}{*}{$\begin{array}{l}\text { Countries with Undervalued } \\
\text { Exchange Rate }\end{array}$} & \multirow[b]{2}{*}{$\underline{\text { Year }}$} & \multicolumn{2}{|c|}{ Total Affiliates } & \multicolumn{2}{|c|}{$\begin{array}{l}\text { Related-Party } \\
\text { Exporters }\end{array}$} & \multicolumn{2}{|c|}{ non-Exporters } \\
\hline & & $\underline{\text { Count }}$ & $\frac{\text { Growth }}{\text { Rate }}$ & $\underline{\text { Count }}$ & $\frac{\text { Growth }}{\text { Rate }}$ & $\underline{\text { Count }}$ & $\frac{\text { Growth }}{\underline{\text { Rate }}}$ \\
\hline & & & & & & & \\
\hline & 1994 & 1268 & - & 395 & - & 753 & - \\
\hline & 1999 & 1811 & $42.8 \%$ & 371 & $-6.1 \%$ & 1338 & $77.7 \%$ \\
\hline & 2004 & 1368 & $-24.5 \%$ & 645 & $73.9 \%$ & 624 & $-53.4 \%$ \\
\hline & 2009 & 1527 & $11.6 \%$ & 710 & $10.1 \%$ & 703 & $12.7 \%$ \\
\hline & 1994-2009 & 259 & $20.4 \%$ & 315 & $79.7 \%$ & -50 & $-6.6 \%$ \\
\hline \multicolumn{8}{|l|}{$\begin{array}{l}\text { Countries with Overvalued } \\
\text { Exchange Rate }\end{array}$} \\
\hline & 1994 & 12038 & - & 5101 & - & 5740 & - \\
\hline & 1999 & 12463 & $3.5 \%$ & 3775 & $-26.0 \%$ & 7904 & $37.7 \%$ \\
\hline & 2004 & 9223 & $-26.0 \%$ & 4049 & $7.3 \%$ & 4376 & $-44.6 \%$ \\
\hline & 2009 & 9662 & $4.8 \%$ & 3506 & $-13.4 \%$ & 5406 & $23.5 \%$ \\
\hline & 1994-2009 & -2376 & $-19.7 \%$ & -1595 & $-31.3 \%$ & -334 & $-5.8 \%$ \\
\hline
\end{tabular}

Differences in Growth Rates, 1994-2009 (Undervalued vs.

Overvalued)

$40.2 \%$ $111.0 \%$ $-0.8 \%$

Note: The sample is the population of U.S. multinationals with majority owned affiliates taken from the quinquennial benchmark surveys over the period 1994-2009. Countries are grouped by sustained currency overvaluation (1990-2009 period average $\leq-.1)$ and sustained currency undervaluation (1990-2009 period average $\geq .1$ ). 
TABLE 4. Bilateral Real Exchange Rate Undervaluation and Trade Disputes, 1980-2011

\begin{tabular}{|c|c|c|c|}
\hline & (1) & (2) & (3) \\
\hline & $\begin{array}{c}\text { All product } \\
\text { filings }\end{array}$ & $\begin{array}{l}\text { All } \\
\text { product } \\
\text { fillings }\end{array}$ & $\begin{array}{c}1997- \\
2011 \\
\text { sample }\end{array}$ \\
\hline Disputes $_{\mathrm{t}-1}$ & $\begin{array}{c}0.269 * * * \\
(0.074)\end{array}$ & & $\begin{array}{c}0.195 * * \\
(0.098)\end{array}$ \\
\hline Undervaluation $_{\mathrm{t}-1}$ & $\begin{array}{c}0.817 * * * \\
(0.238)\end{array}$ & $\begin{array}{c}0.875 * * * \\
(0.263)\end{array}$ & $\begin{array}{c}1.002 * * * \\
(0.302)\end{array}$ \\
\hline GDP/capita ${ }_{t-3}$ & $\begin{array}{c}0.566 * * * \\
(0.158)\end{array}$ & $\begin{array}{c}0.54^{* * *} \\
(0.17)\end{array}$ & $\begin{array}{c}0.455^{* * *} \\
(0.161)\end{array}$ \\
\hline Polity $\mathrm{t}_{\mathrm{-}}$ & $\begin{array}{c}0.053 * * \\
(0.023)\end{array}$ & $\begin{array}{c}0.056 * * \\
(0.026)\end{array}$ & $\begin{array}{c}0.096 * * * \\
(0.034)\end{array}$ \\
\hline $\begin{array}{l}\text { Bilateral Trade } \\
\text { Balance }_{\mathrm{t}-2}\end{array}$ & $\begin{array}{c}-1.173^{* * *} \\
(0.274)\end{array}$ & $\begin{array}{c}-2.198 * * * \\
(0.35)\end{array}$ & $\begin{array}{c}-1.92 * * * \\
(0.489)\end{array}$ \\
\hline $\begin{array}{l}\text { Capital Account } \\
\text { Openness }_{\mathrm{t}-1}\end{array}$ & $\begin{array}{c}-0.009 * * \\
(0.004)\end{array}$ & $\begin{array}{c}-0.009 * * \\
(0.004)\end{array}$ & $\begin{array}{c}-0.19 * * * \\
(0.006)\end{array}$ \\
\hline $\begin{array}{l}\text { Bilateral Invest } \\
\text { Treaty }_{\mathrm{t}-1}\end{array}$ & $\begin{array}{c}-0.617 * * \\
(0.314)\end{array}$ & $\begin{array}{c}-0.722 * * \\
(0.323)\end{array}$ & $\begin{array}{l}-0.9 * * * \\
(0.304)\end{array}$ \\
\hline \multicolumn{4}{|c|}{ Model of Excess Zeros } \\
\hline Disputes $_{\mathrm{t}-3}$ & $\begin{array}{c}-14.264^{* * *} \\
(2.792) \\
\end{array}$ & $\begin{array}{c}-2.954 * * * \\
(0.643) \\
\end{array}$ & $\begin{array}{c}-17.0 * * * \\
(0.558) \\
\end{array}$ \\
\hline Log-likelihood & -1345.9 & -1377.3 & -549.13 \\
\hline Observations & 2814 & 2814 & 1472 \\
\hline Countries & 109 & 109 & 109 \\
\hline Vuong statistic & 3.74 & 5.44 & 2.75 \\
\hline
\end{tabular}

Note: The table reports the results of panel zero-inflated negative binomial estimates of annual bilateral antidumping filings in the United States, with and without a lagged endogenous variable ( 1 and 2, respectively). Model 3 examines filings over the period 1997-2001. The variables are defined in the text. 
TABLE 5. Undervaluation, Imports, and Trade Disputes

\begin{tabular}{|c|c|c|c|c|c|c|}
\hline & (1) & $(2)$ & (3) & (4) & (5) & (6) \\
\hline & & & & & Predicted RP & Investment \\
\hline Disputes $_{\mathrm{t}-1}$ & $\begin{array}{c}0.269 * * * \\
(0.091)\end{array}$ & $\begin{array}{c}0.196 * * * \\
(0.063)\end{array}$ & & $\begin{array}{l}0.147 * * \\
(0.071)\end{array}$ & $\begin{array}{c}0.233 * * \\
(0.071)\end{array}$ & $\begin{array}{c}0.241 * * * \\
(0.073)\end{array}$ \\
\hline Undervaluation $_{\mathrm{t}-1}$ & $\begin{array}{c}0.395 \\
(0.256)\end{array}$ & $\begin{array}{l}-0.489 * \\
(0.279)\end{array}$ & $\begin{array}{c}-0.62 \\
(0.381)\end{array}$ & $\begin{array}{c}0.081 \\
(0.388)\end{array}$ & $\begin{array}{l}1.032^{* *} \\
(0.438)\end{array}$ & $\begin{array}{c}0.470 \\
(0.348)\end{array}$ \\
\hline U.S. Arm's-Length Imports ${ }_{\mathrm{t}-1}$ & $\begin{array}{c}0.757 \\
(0.653)\end{array}$ & $\begin{array}{l}4.126^{* * *} \\
(1.271)\end{array}$ & $\begin{array}{l}4.58 * * * \\
(1.328)\end{array}$ & $\begin{array}{l}4.471^{* * *} \\
(1.599)\end{array}$ & $\begin{array}{l}12.621^{*} \\
(7.367)\end{array}$ & $\begin{array}{l}3.526 * * * \\
(1.195)\end{array}$ \\
\hline U.S. Related-party Imports $_{\mathrm{t}-1}$ & $\begin{array}{c}0.966 * * * \\
(0.350)\end{array}$ & $\begin{array}{c}0.282 \\
(0.482)\end{array}$ & $\begin{array}{c}0.073 \\
(0.564)\end{array}$ & $\begin{array}{l}-0.068 \\
(0.596)\end{array}$ & $\begin{array}{c}-13.387 \\
(9.11)\end{array}$ & \\
\hline $\begin{array}{l}\text { Undervaluation }_{\mathrm{t}-1} \mathrm{x} \\
\text { U.S. Related-party Imports } \mathrm{I}_{\mathrm{t}-1}\end{array}$ & & $\begin{array}{c}-6.442 * * * \\
(1.861)\end{array}$ & $\begin{array}{c}-7.181 * * * \\
(1.861)\end{array}$ & $\begin{array}{c}-7.603 * * * \\
(2.449)\end{array}$ & $\begin{array}{c}-67.31 * * * \\
(31.22)\end{array}$ & \\
\hline $\begin{array}{l}\text { Undervaluation }_{\mathrm{t}-1} \mathrm{x} \\
\text { U.S. Arm's-Length Imports } \text { Im-1 }_{\mathrm{t}}\end{array}$ & & $\begin{array}{c}22.433 * * * \\
(5.234)\end{array}$ & $\begin{array}{c}24.46^{* * *} \\
(5.296)\end{array}$ & $\begin{array}{c}24.508 * * * \\
(7.121)\end{array}$ & $\begin{array}{c}56.834 * * * \\
(17.635)\end{array}$ & $\begin{array}{l}6.248 * \\
(3.211)\end{array}$ \\
\hline GDP/capita ${ }_{t-3}$ & & & & $\begin{array}{c}0.557 * * * \\
(0.120)\end{array}$ & $\begin{array}{l}0.51^{* * *} \\
(0.147)\end{array}$ & $\begin{array}{c}0.439 * * * \\
(0.132)\end{array}$ \\
\hline Polity $_{\mathrm{t}-1}$ & & & & $\begin{array}{l}0.071^{* *} \\
(0.028)\end{array}$ & $\begin{array}{l}0.071^{* *} \\
(0.035)\end{array}$ & $\begin{array}{l}0.075^{* *} \\
(0.035)\end{array}$ \\
\hline Capital Account Openness ${ }_{\mathrm{t}-1}$ & & & & $\begin{array}{c}-0.019 * * * \\
(0.005)\end{array}$ & $\begin{array}{c}-0.022 * * * \\
(0.006)\end{array}$ & $\begin{array}{c}-0.020 * * * \\
(0.006)\end{array}$ \\
\hline Bilateral Investment Treaty & & & & $\begin{array}{l}-0.444 \\
(0.299)\end{array}$ & $\begin{array}{c}-0.6^{*} \\
(0.313)\end{array}$ & $\begin{array}{c}-0.708^{* *} \\
(0.316)\end{array}$ \\
\hline U.S. Inward FDI $\mathrm{t}_{\mathrm{t}-1}$ & & & & & & $\begin{array}{l}-137.936 \\
(84.055)\end{array}$ \\
\hline Undervaluation $_{\mathrm{t}-1} \mathrm{x}$ U.S. Inward FDI $\mathrm{FI}_{\mathrm{t}-1}$ & & & & & & $\begin{array}{l}-408.022 * \\
(235.290)\end{array}$ \\
\hline$\frac{\text { Model of Excess Zeros }}{\text { Disputes }_{\mathrm{t}-3}}$ & $\begin{array}{c}-16.915 * * * \\
(0.446)\end{array}$ & $\begin{array}{c}-17.109 * * * \\
(0.397)\end{array}$ & $\begin{array}{c}-16.99 * * * \\
(0.454)\end{array}$ & $\begin{array}{c}-16.301 * * * \\
(0.486)\end{array}$ & $\begin{array}{c}-17.91 * * * \\
(0.486)\end{array}$ & $\begin{array}{c}-16.552 * * * \\
(0.501)\end{array}$ \\
\hline Log-likelihood & -583.651 & -565.603 & -567.775 & -528.109 & -484.62 & -528.340 \\
\hline Observations & 1580 & 1580 & 1580 & 1472 & 1241 & 1337 \\
\hline Countries & 113 & 113 & 113 & 109 & 108 & 108 \\
\hline Vuong statistic & 3.242 & 3.079 & 3.73 & 2.397 & 2.15 & 2.327 \\
\hline
\end{tabular}

Note: See notes to the prior table. 
TABLE 6. Undervaluation, Imports, and Antidumping Filings against Chinese Firms

\begin{tabular}{|c|c|c|c|}
\hline & (1) & (2) & (3) \\
\hline Disputes $_{\mathrm{t}-1}$ & & $\begin{array}{l}0.072 * \\
(0.040)\end{array}$ & $\begin{array}{c}0.008 \\
(0.034)\end{array}$ \\
\hline Undervaluation $_{\mathrm{t}-1}$ & $\begin{array}{l}1.610^{* *} \\
(0.639)\end{array}$ & $\begin{array}{c}0.743 \\
(0.687)\end{array}$ & $\begin{array}{c}-6.607^{* *} \\
(2.719)\end{array}$ \\
\hline U.S. Arm's-length Importst & & & $\begin{array}{c}4.473 * * * \\
(1.336)\end{array}$ \\
\hline U.S. Related-party Imports $\mathrm{s}_{\mathrm{t}-1}$ & & & $\begin{array}{c}-6.914 * * \\
(2.944)\end{array}$ \\
\hline Constant & $\begin{array}{c}1.578 * * * \\
(0.147)\end{array}$ & $\begin{array}{c}1.212 * * * \\
(0.252)\end{array}$ & $\begin{array}{l}-0.254 \\
(0.609)\end{array}$ \\
\hline Log-likelihood & -85.097 & -82.363 & -31.347 \\
\hline Observations & 33 & 32 & 15 \\
\hline
\end{tabular}

Note: The table reports the results of negative binomial estimates of annual antidumping filings against China by complainants in the United States. The independent variables are country-year values corresponding to China. The undervaluation index is defined in the text; higher values indicate greater real exchange rate undervaluation relative to the U.S. dollar. Related imports and arm's-length imports measure U.S. imports from China by affiliated and unaffiliated parties, respectively, as a share of U.S. GDP. 


\section{Appendix}

Table A1. Undervaluation and MNC Investment, 1994-2009

\begin{tabular}{|c|c|c|c|}
\hline & (1) & $(2)$ & (3) \\
\hline & $\Delta$ Affiliates & $\begin{array}{l}\Delta \text { Related- } \\
\text { party } \\
\text { Exporters }\end{array}$ & $\begin{array}{c}\Delta \text { Non- } \\
\text { Exporters }\end{array}$ \\
\hline Undervaluation & $\begin{array}{l}0.130 * \\
(0.077)\end{array}$ & $\begin{array}{c}0.246^{* * *} \\
(0.053)\end{array}$ & $\begin{array}{c}0.075 \\
(0.083)\end{array}$ \\
\hline 2004 & $\begin{array}{c}-0.407 * * * \\
(0.064)\end{array}$ & $\begin{array}{c}0.413^{* * *} \\
(0.062)\end{array}$ & $\begin{array}{c}-0.869 * * * \\
(0.077)\end{array}$ \\
\hline 2009 & $\begin{array}{c}-0.135^{* *} \\
(0.054)\end{array}$ & $\begin{array}{c}0.196 * * * \\
(0.055)\end{array}$ & $\begin{array}{c}-0.323 * * * \\
(0.062)\end{array}$ \\
\hline Constant & $\begin{array}{c}0.113 * * \\
(0.045)\end{array}$ & $\begin{array}{c}-0.175^{* * *} \\
(0.040)\end{array}$ & $\begin{array}{c}0.288 * * * \\
(0.048)\end{array}$ \\
\hline Observations & 368 & 368 & 368 \\
\hline Countries & 123 & 123 & 123 \\
\hline R-squared & 0.139 & 0.158 & 0.337 \\
\hline
\end{tabular}

Note: The table reports the results of models of the changes in the number of affiliates of U.S. MNCs in three separate categories: Total Affiliates, affiliates with positive sales to affiliated parties in the U.S. or in other countries (Related-party Exporters), and affiliates that do not export (Non-Exporters). Undervaluation corresponds to the average value of Undervaluation for the 5-year period prior to and including the benchmark year. Robust standard errors are clustered at the country-level. 


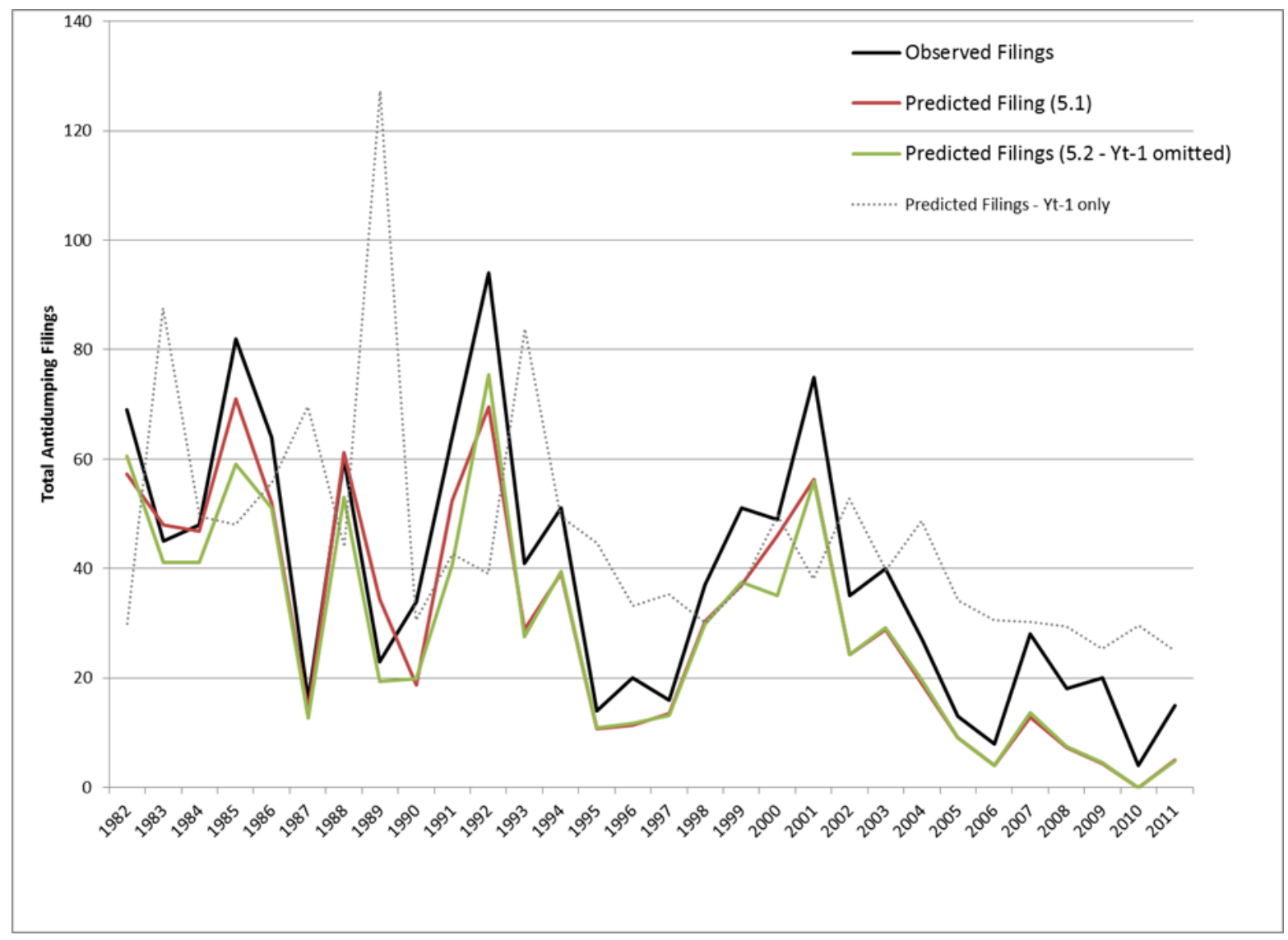

FIGURE A1. Actual vs. Predicted Trade Disputes. (Derived from results in models 1 (with Yt-1) and 2 (without), Table 5.) 